\title{
دور التوترات الاجتماعية في تفشي الممارسات السحرية و الشعوذية في المجتمع التونسي دراسة سوسيولوجية ميدانية
}

الدكتور : سعيد الحسين عبدولي

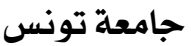

تكمن عديد العوامل التي تتصل بحاجيات الجمتمع وبالرصيد الثقافي

للفاعلين وراء انتشار ظاهرتي السحر والشعوذة في أيّ بجتمع. فبروز

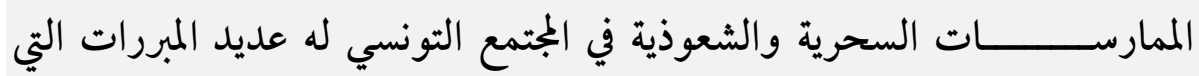
يتوجّب علينا تحليلها ومناقشتها لكونها تمّّل أحد أبرز مقاصدنا الاشكالية وستبحث دراستنا في العلاقة بين التوترات الاجتماعية من ناحية و هذه الظاهرة من ناحية ثانية.

Résumé :

Les motifs relatifs de la propagation de la magie et la sorcellerie dans une société sont reliés à un besoin social et à un héritage culturel. Dès lors, l'apparition de ces pratiques (de la magie) dans la société tunisienne à plusieurs raisons qu'on doit analyser et discuter vu que cet axe représente notre principal centre d'intérêt. Notre étude concernera d'une part la relation entre les perturbations sociales et d'une autre part ce phénomène de magie et sorcellerie. 
ما علاقة البخور وترديد التعويذات الغامضة الممزوجة أحيانا بآيات

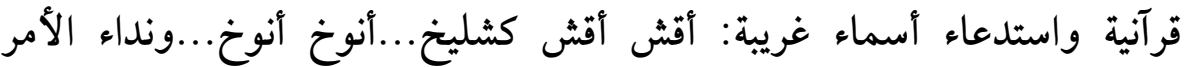

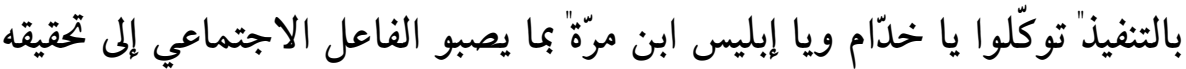

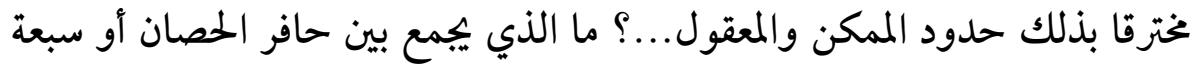

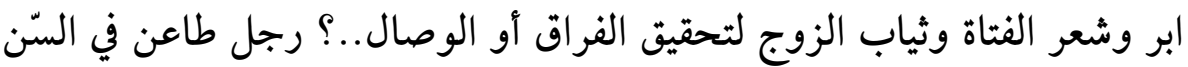

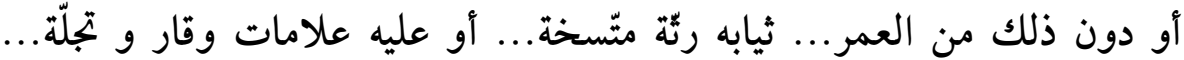

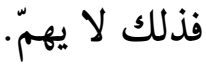

ربما لكونه أمر داخل في تقاليد المهنة...امرأة أو رجل مسكون من طرف إن إن

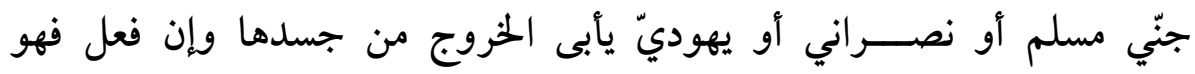

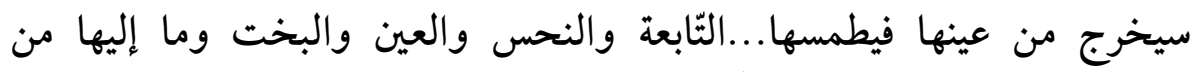

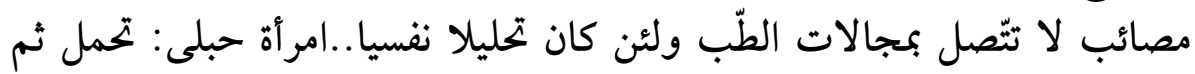

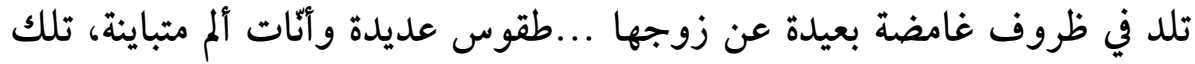

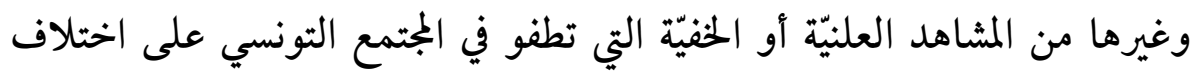

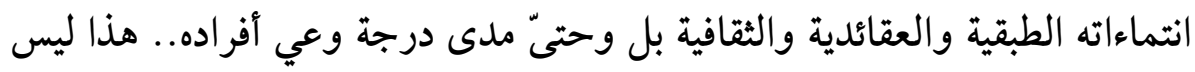

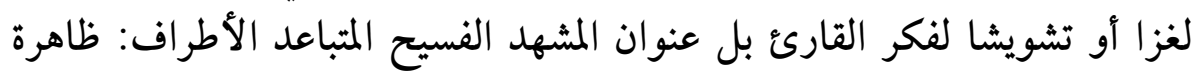

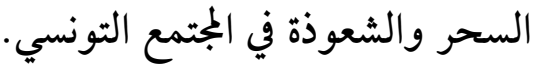

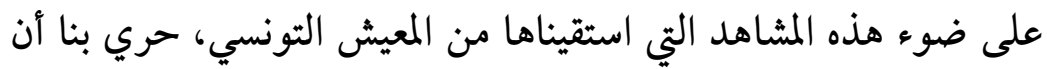

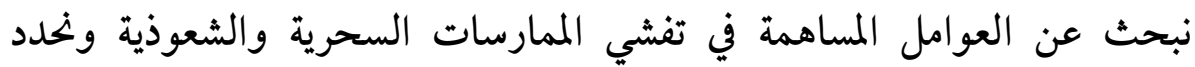

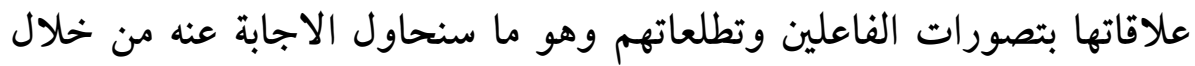

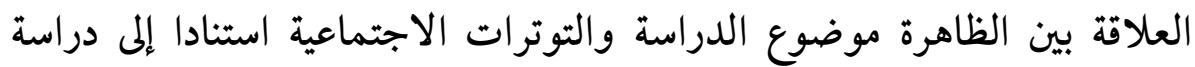

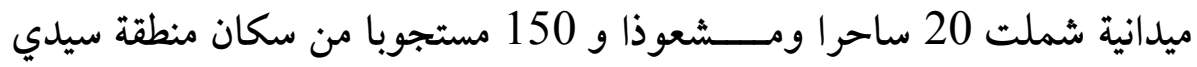
علي بن عون من ولاية سيدي بوزيد. 
1. التأسيسات النظرية للدراسة:( الباراديقم)

$$
\text { تعريف السحر: }
$$

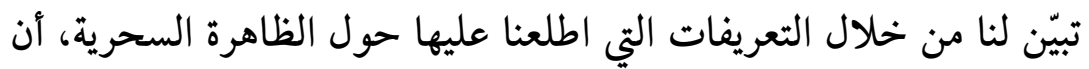

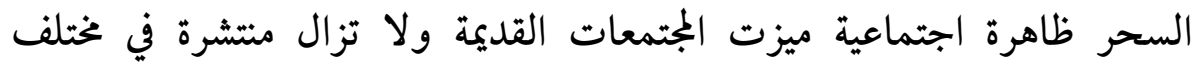

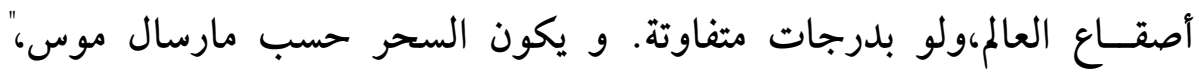

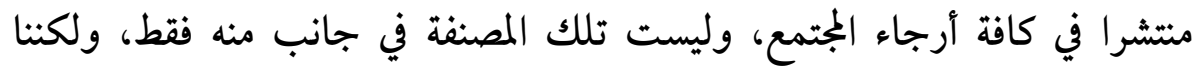

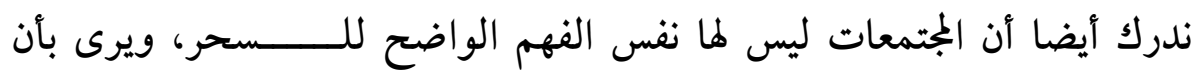

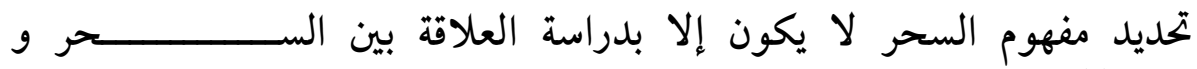
الدين

يكون السحر إذا في ضوء هذا الفهم، كل الأنشطة التي يمارســـــــــاهـ

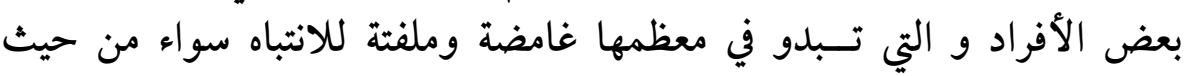

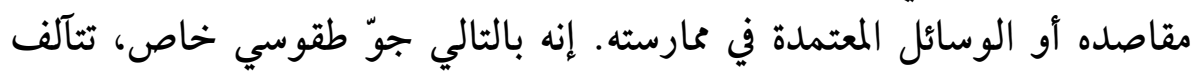

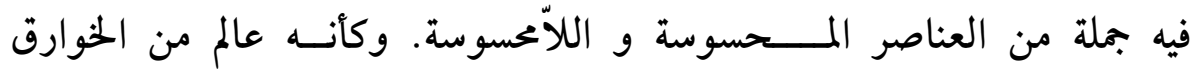

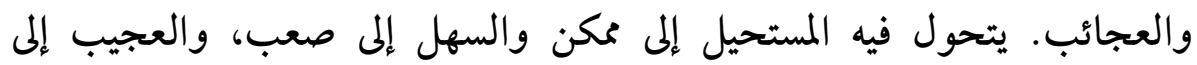

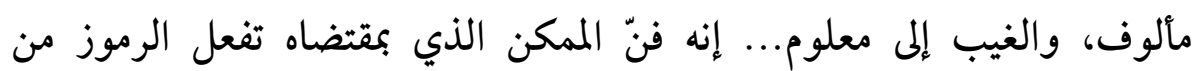

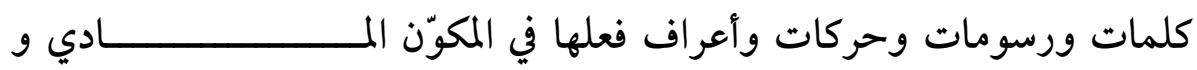

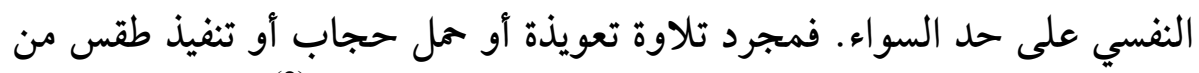

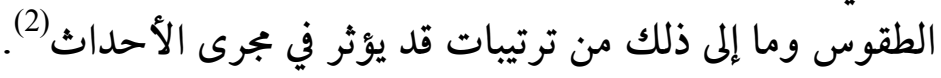

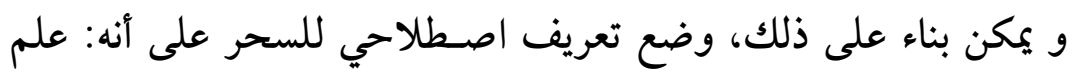

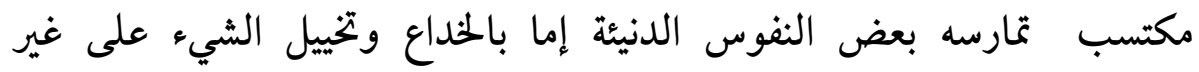

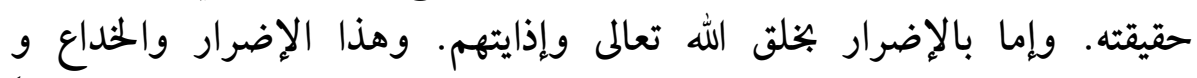

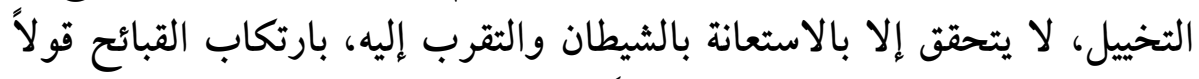

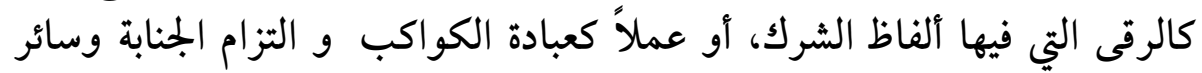

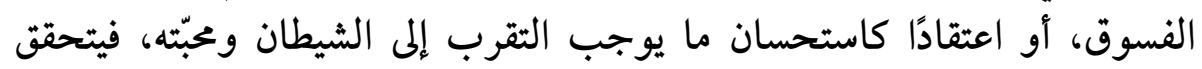
بذلك تأثير السحر في المسحور. 
إن الشعوذة ولئن كانت تشترك مع السّحر في بعض الجوانب، فإنها لا لانيّا

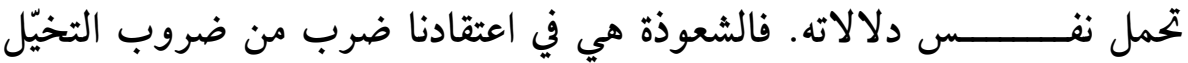

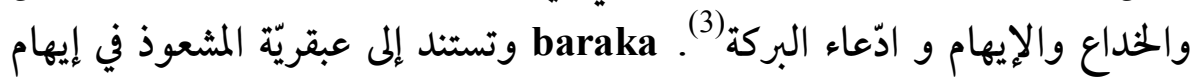

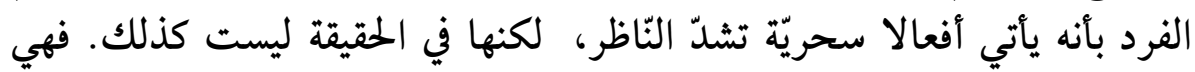

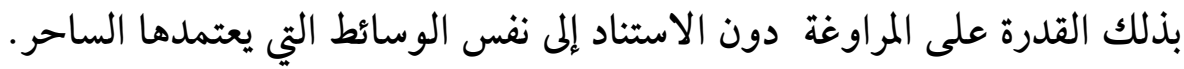

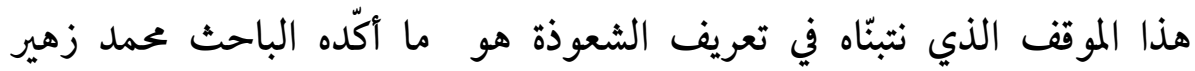

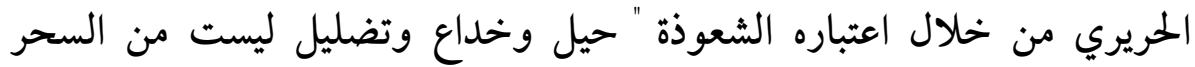

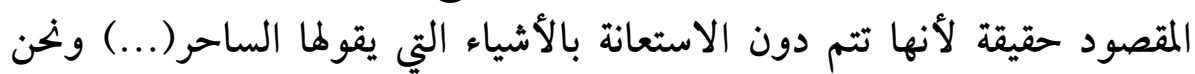

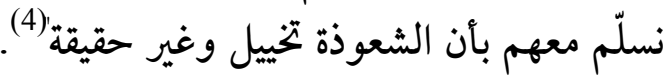

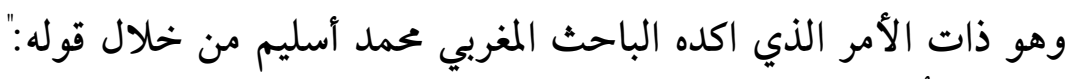

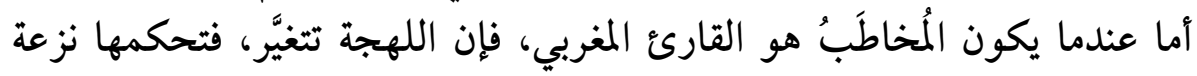

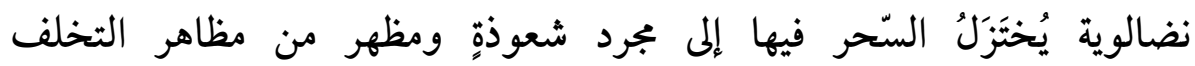

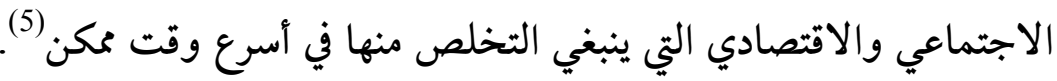

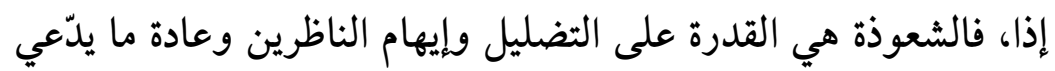

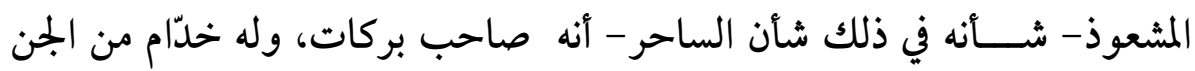

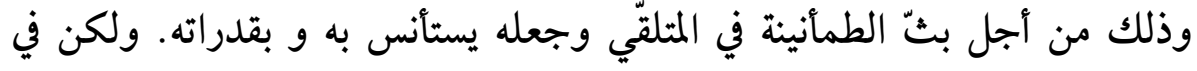

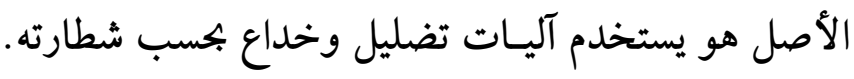

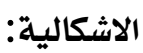

سنولي اهتمامنا بدراسة الفاعلين وتفاعلاتهم وتصوراتهم حول هذه التها

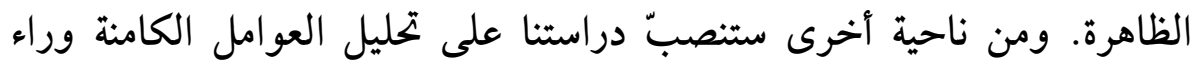

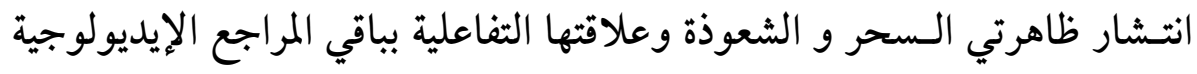

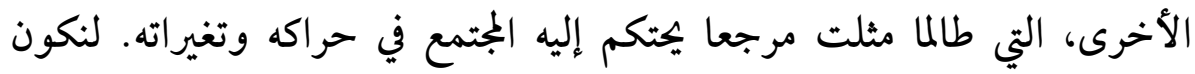

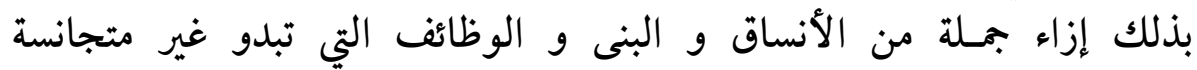




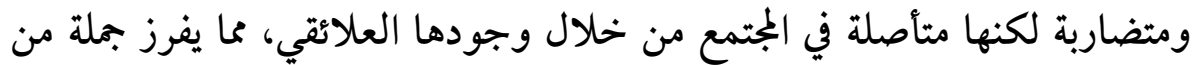

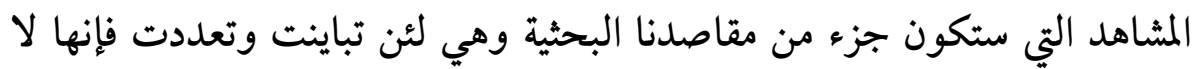

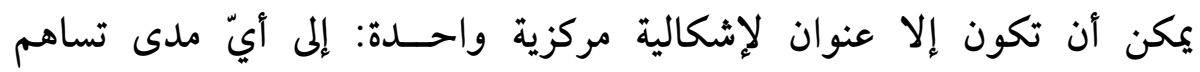

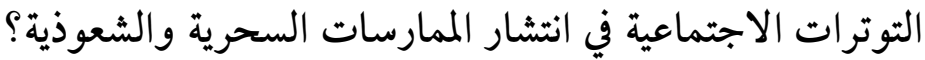
وفي حدود بجثنا هذا الذي سيهتم بعلاقة التوترات الاجتماعية بانتشار

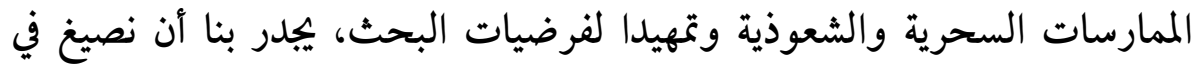
ضوء الإشكالية الرئيسية، الإشكالية الفرعية على النحو الآتي:

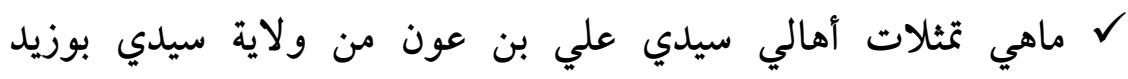

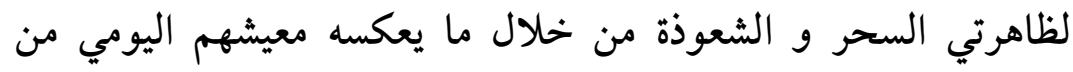

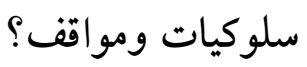
ل كيف يكن أن تساهم التوترات الاجتماعية في إنتشار ظاهرتي السحر و و

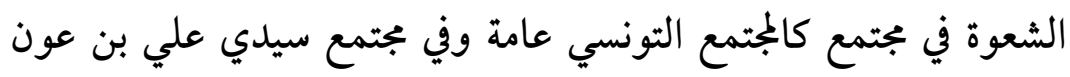

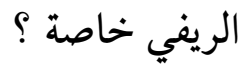

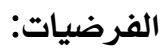

لو توقفنا عند هذا الأمر وتبخرّنا فيه بحثا عن الفرضيات الملائمة لدراستنا

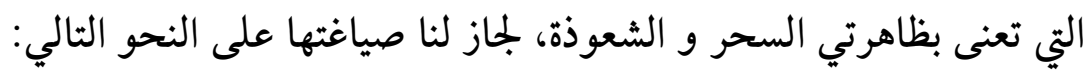

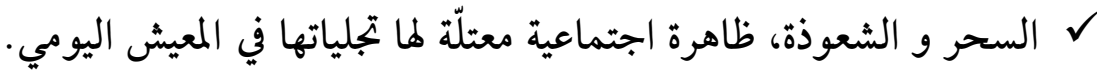

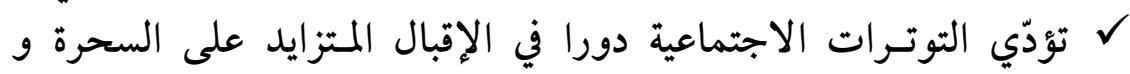
المشعوذين من طرف الفاعلين.

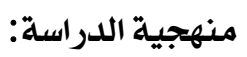

سنعمد إلى استخدام المنهجيــن الكمــي و الكيفي، نظرا لطبيعة الظاهرة

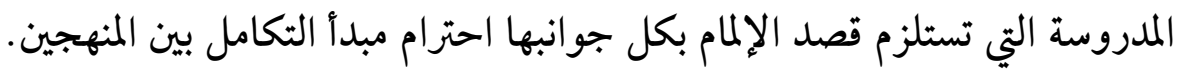

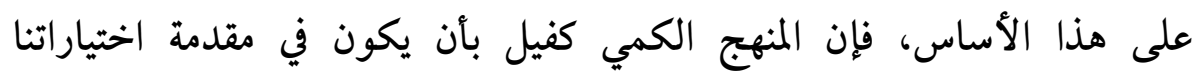

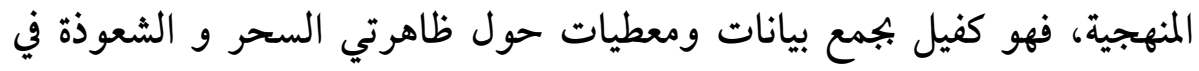




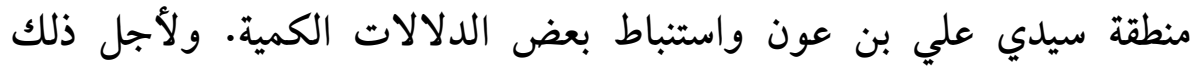

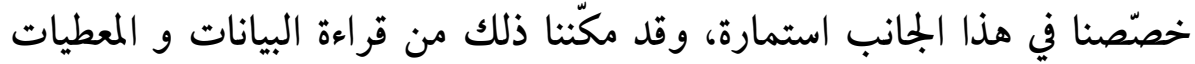

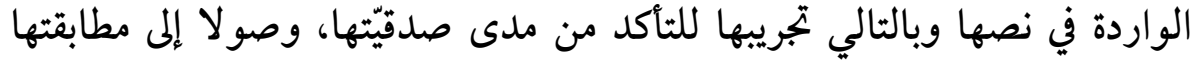

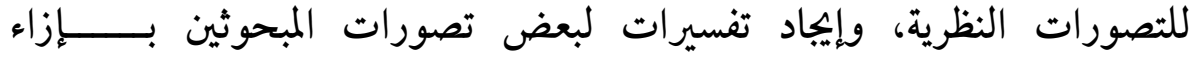

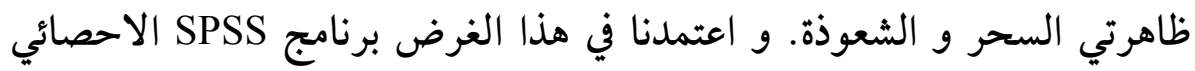

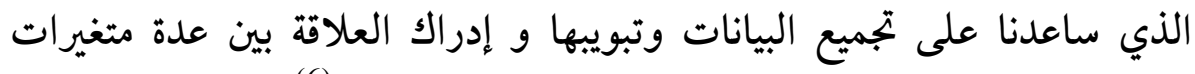
ومقارنتها بالقراءات النظرية حول الظاهرة موضون البيات وتئها و الدراسة (6).

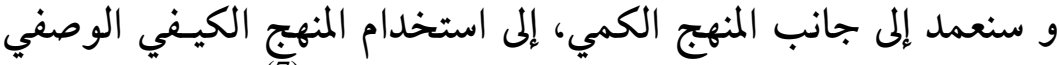

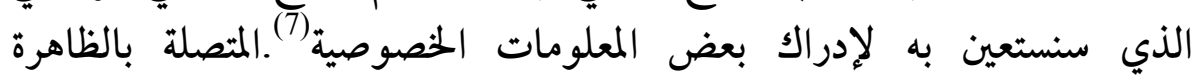

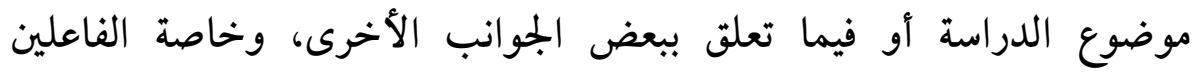

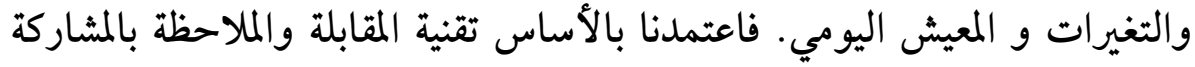

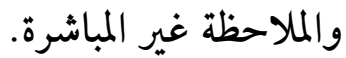

1.5. الاطار النظري العام:(الباراديقم)

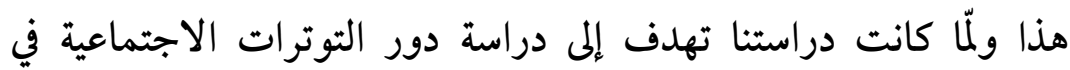

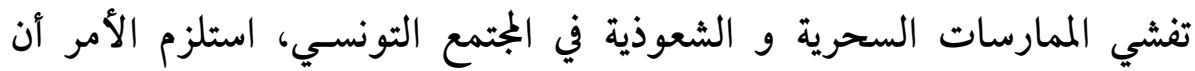

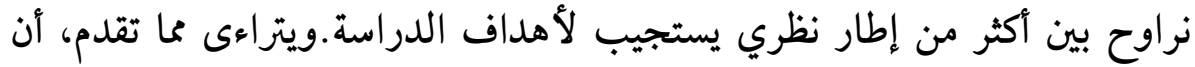

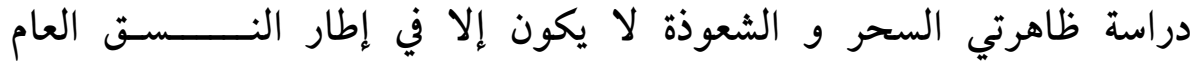

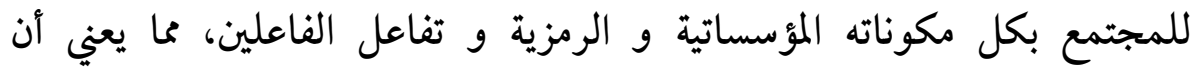

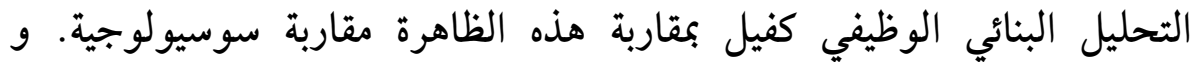

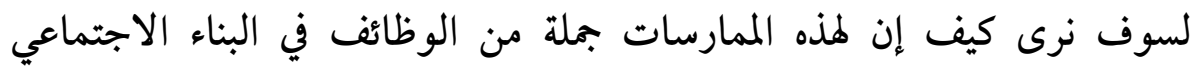
التونسي وكذلك في مستوى السلوك أو التصورات والمعتقدات أو أنماط التفكير.

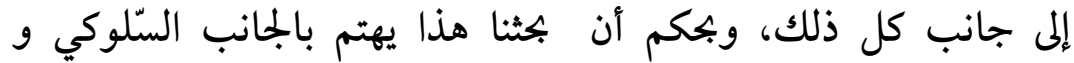

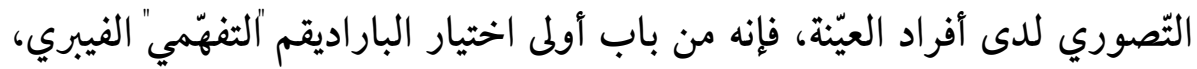

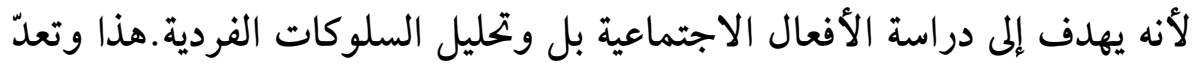


التفاعلية الرمزية، إطارا نظريا أمكن تبنيه، فيمكن القول إنها من الأهمية بمكان في بحثنا وتعد مكمّلة لسابقاتها لفهم الظاهرة المدروسة.

2. دور التوترات الاجتماعية: دوافع الواقع المعيش، في تفشي الممارسات السحرية و

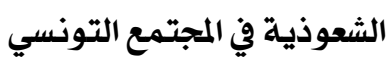

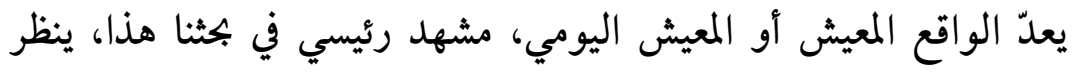

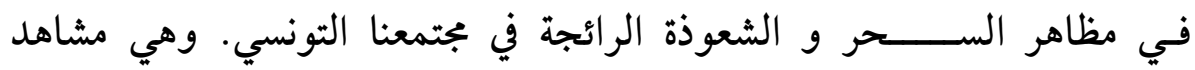

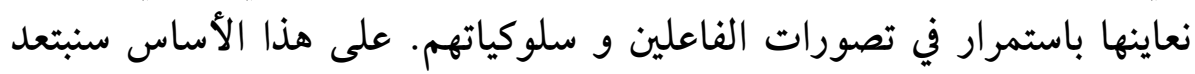

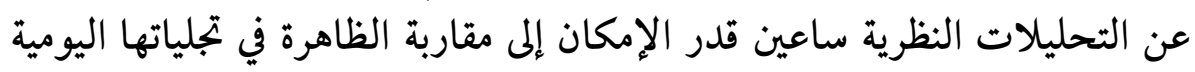

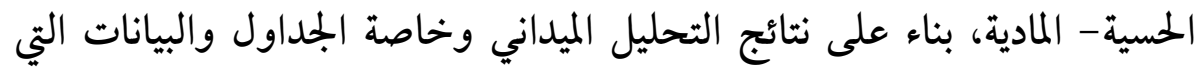
توصلنا إليها فضلا عن المقابلات والملاحظات والماتية المعاينات

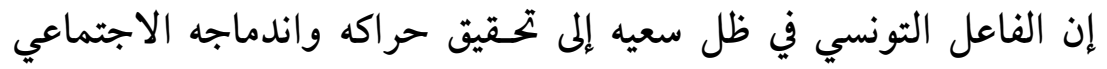

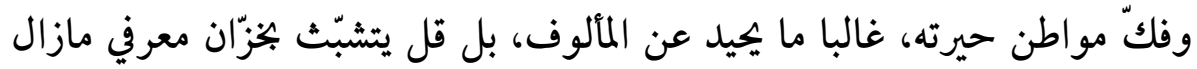

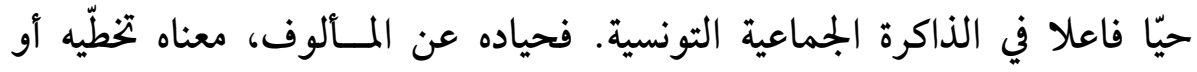

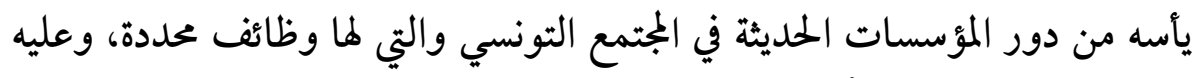

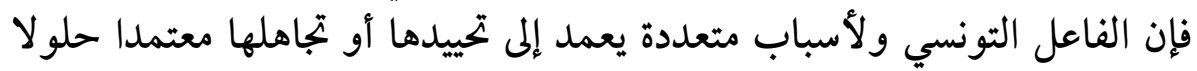
خارجة عن المألوف من القوانين والمؤسسات.

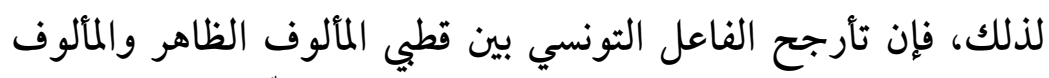

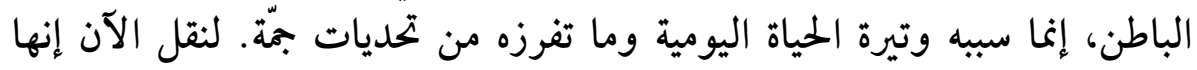

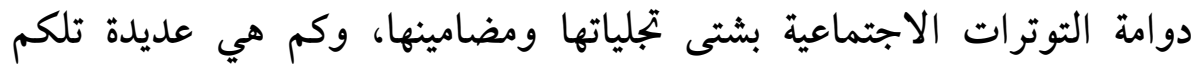

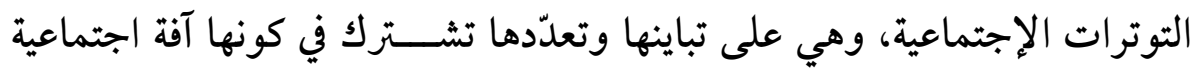

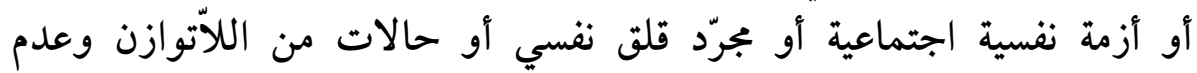

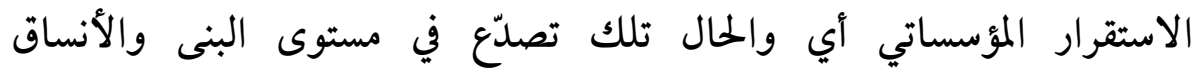
الاجتماعية وكل ذلك بمكن ان يكون من المحفزات على تعلق الفاعلين بالممارسات السحرية والشعوذية كمخرج لهذه التوترات. 
1 2 1 القلق والتوتر من الدوافع المؤدية إلى التعلق بالممارسات السحرية و الشعوذية: يعدّ القلق والتوتر النفسي من المشكلات التي يعانيها الإنسان في ظل

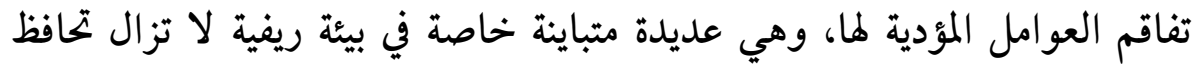

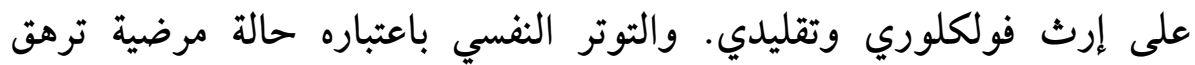

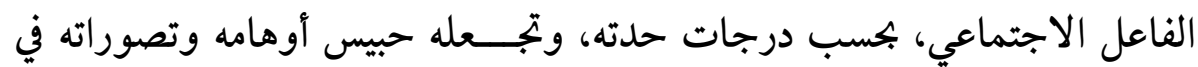

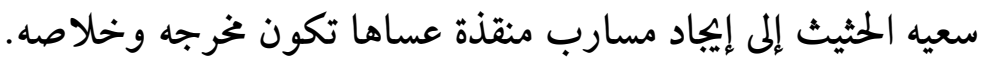
وإزاء هذا الحال، فإن تصرفات الفاعل تفسّر حسب الوضعيات التي يعيــشها: مؤهلاته المادية و الإيديولوجية ورصيده الثقافي وحتى انحداره الطبقي لئي

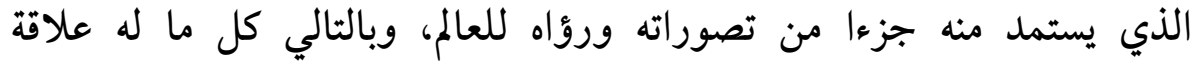

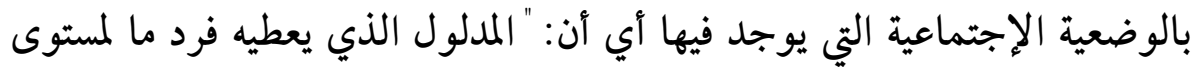
مدرسي معطى يتراوح حسب الوضعية الاجتماعية لهذا الفرد (8). نلاحظ من كل ذلك، أن للسحر كما للشعوذة وظيفة سوسيولوجية، إذ يساهمان في ربط الذات المهزومة ثقافيا وماديا وحتى أخلاقيا واجتماعيا بالعالم

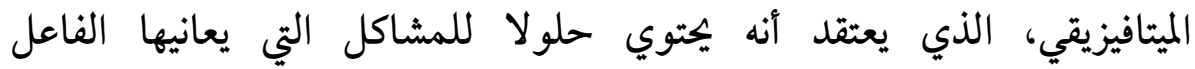

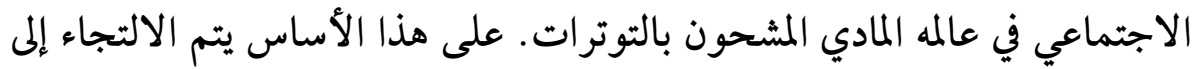

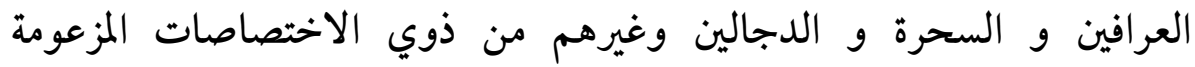
المشحونة بالأوهام والأباطيل رغم نجاعتها المحدودة اجتماعيا ونفسيا، لكونها

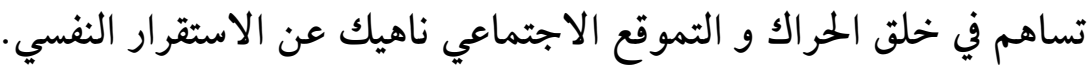

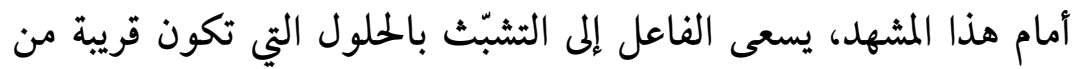

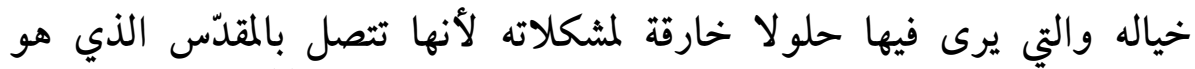

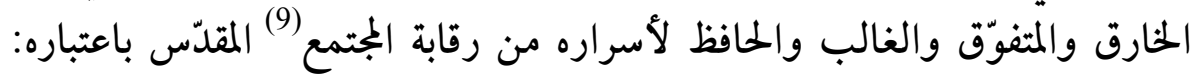

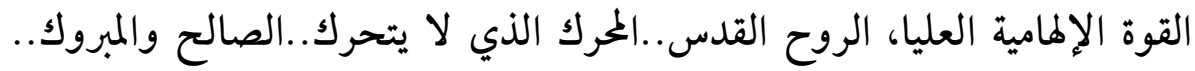

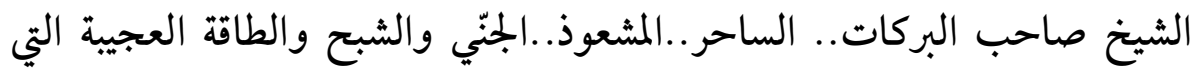


يتمتع بها بعض الأفراد في التحايل والخداع والتي غالبا ما يراها المهزوم نفسيا واجتماعيا سرّ النجاة رغم ما تحتويه من آلام وأكاذيب.

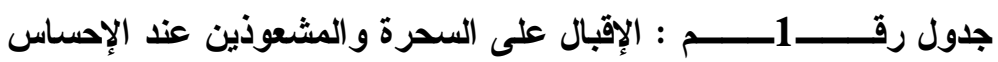

بالقلق و التوتر حسب الجنس والمستوى التطليمي

\begin{tabular}{|c|c|c|c|}
\hline \multirow[t]{2}{*}{ المجموع } & \multicolumn{2}{|c|}{ التكرارات } & \multirow{2}{*}{ السحر لعلاج القلق و التوتر } \\
\hline & لا & نعم & \\
\hline 29 & 21 & 8 & أمتي \\
\hline 8 & 6 & 2 & يقرأ ويكتب \\
\hline 24 & 17 & 7 & تعليم ابتدائي \\
\hline 69 & 50 & 19 & تعليم ثانوي \\
\hline 20 & 15 & 5 & جامعي \\
\hline 150 & 109 & 41 & المجموع \\
\hline$\% 100$ & 72.67 & 27.33 & النسبة \% \% \\
\hline
\end{tabular}

هذا ومن أجل مقاربة مدى صحة ما سبق ذكره بما سبق التلميح إليه في

سؤال الاستمارة نورد المعطيات التالية:

نلاحظ إذا أن قرابة ثلث العينة المستجوبة والمتكونة من 150 فردا، أي

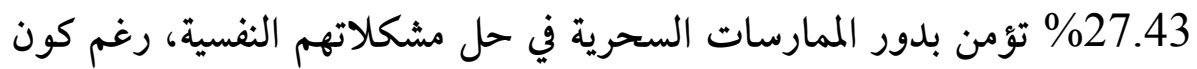

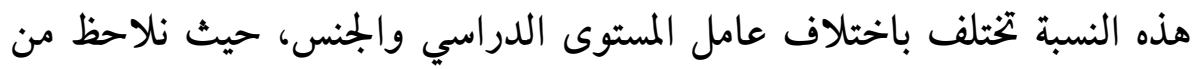

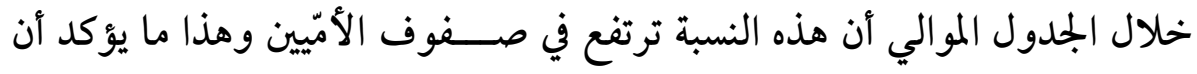

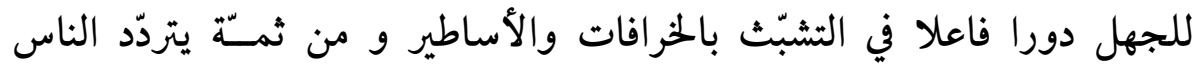

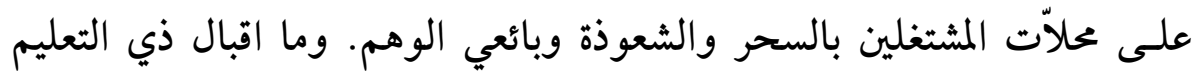

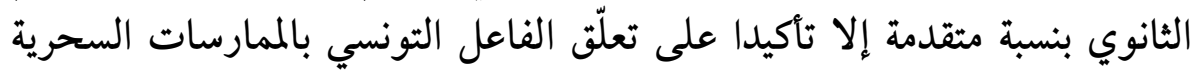


و الشعوذية في تحقيق الحراك الاجتماعي خاصة وأن هذه الفئة من العينة إما أن

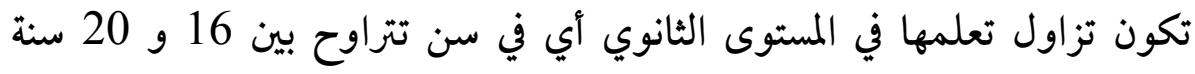

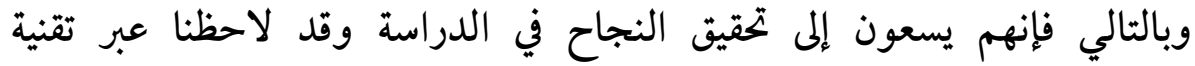

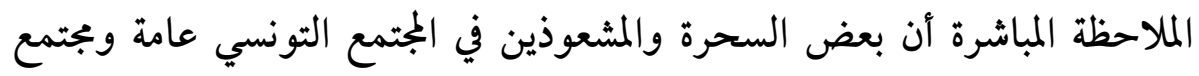

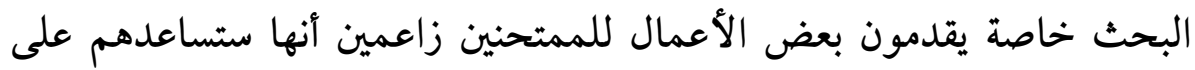

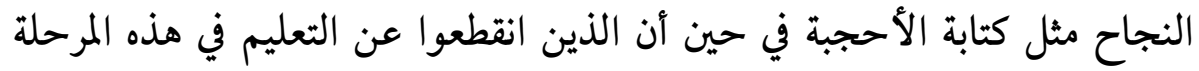

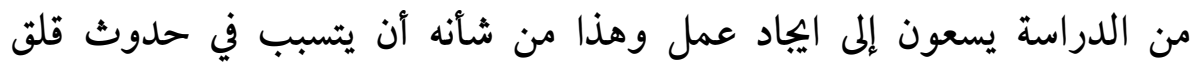

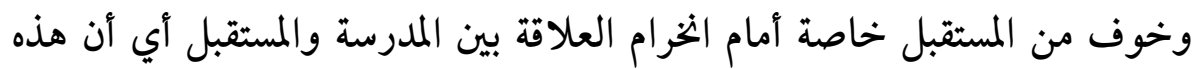
المؤسسة لم تعد ضمانة فعلية للنجاح والحصول على المئل عمل (10).

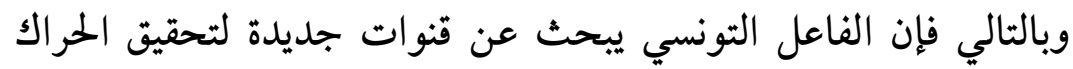

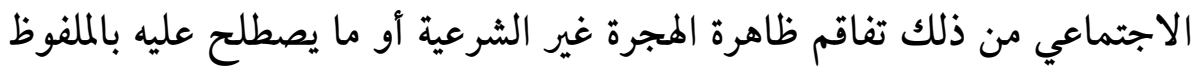

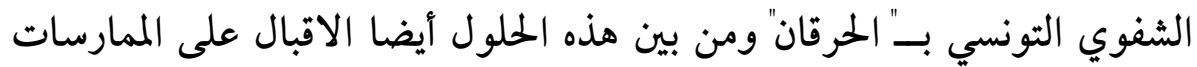

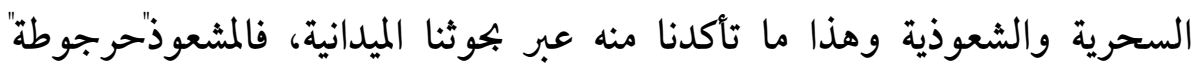
المقيم في سيدي علي بن عون البلدة و الساحر "شوشان الممامي (11).

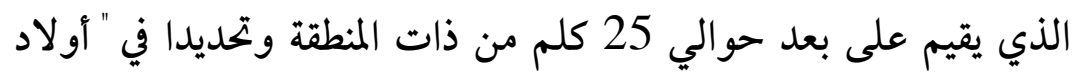

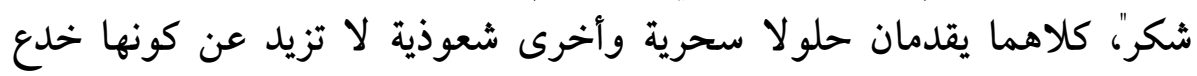

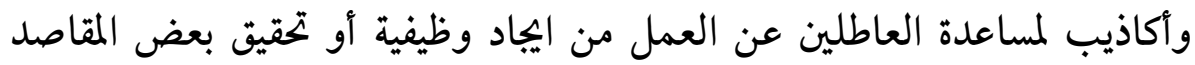

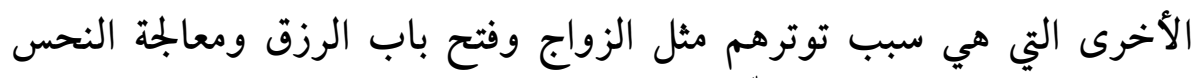

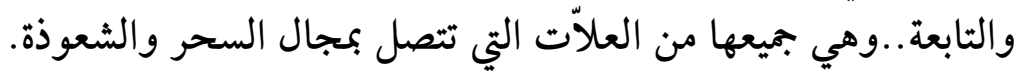

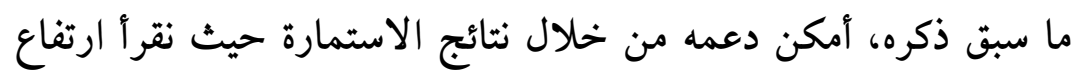

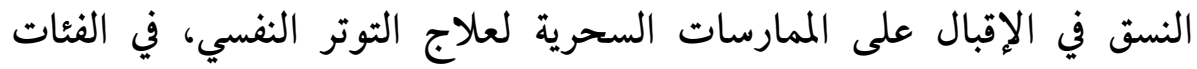

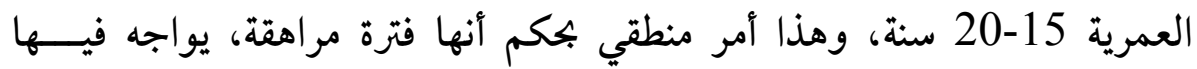

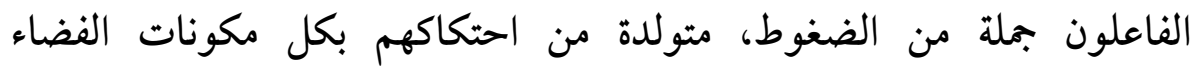

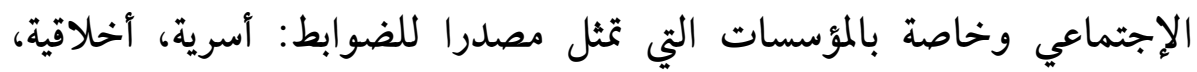

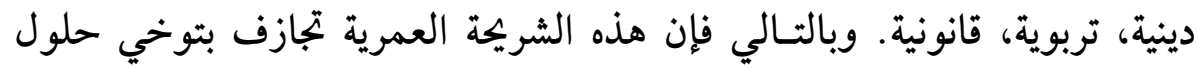


مخالفة من أجل تقليص هذا الضغط والكبت، فيكون الإقـــــبال على السحر

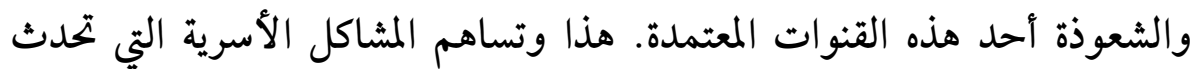

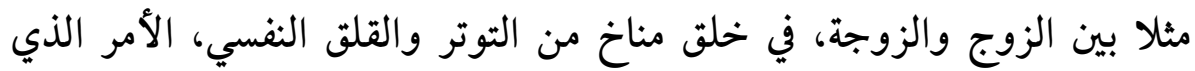

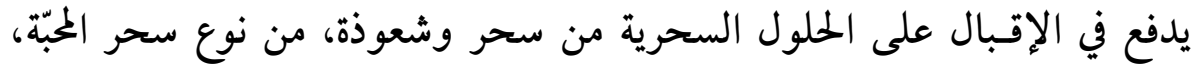

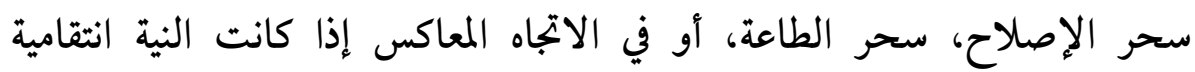
وعدوانية مثل سحر الجنون، سحر التفرقة، سحر التعطيل.

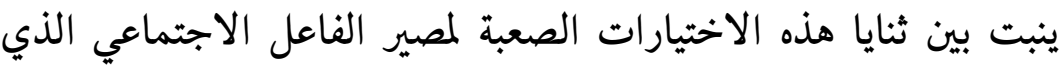

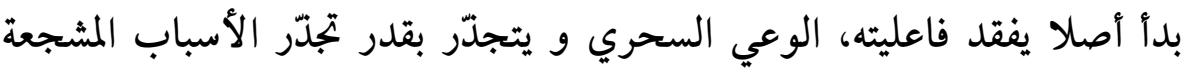

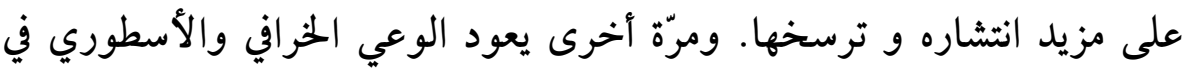

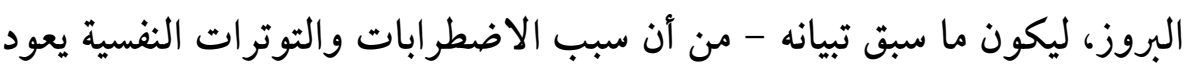

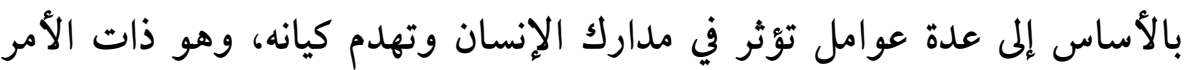

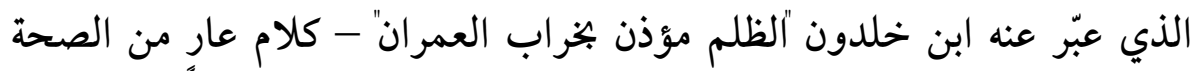

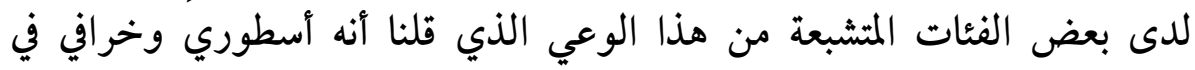

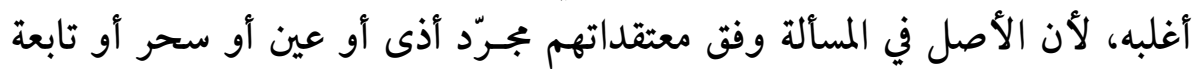

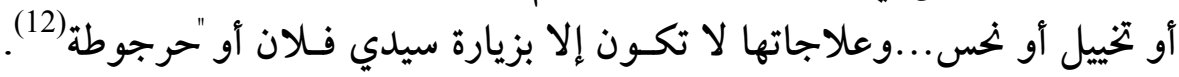

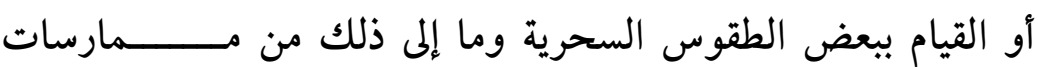

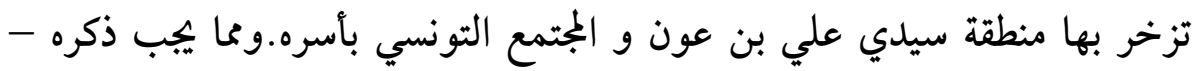

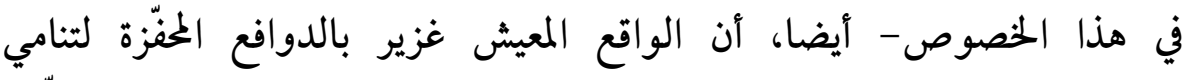

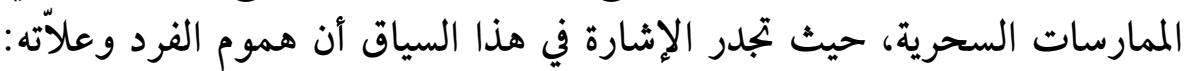

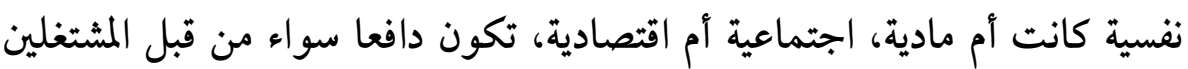

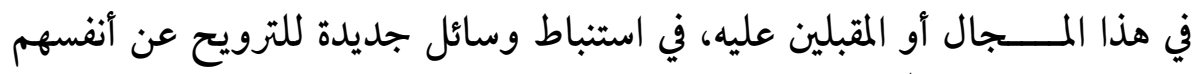

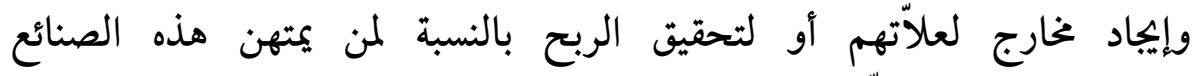

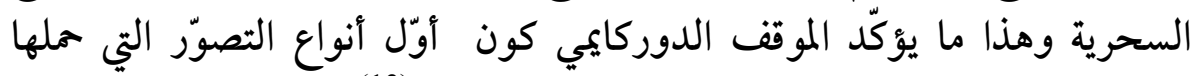
الإنسان حول العالم وحول نفسه كانت ذات طابع ديني (13). 
وهو ذات الأمر الذي أكدته بداك شابحة من خلال قولها:" إن التقاليد

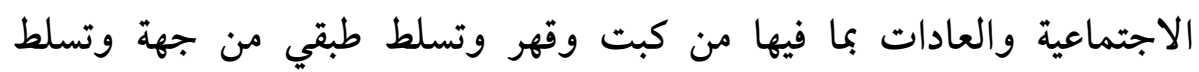

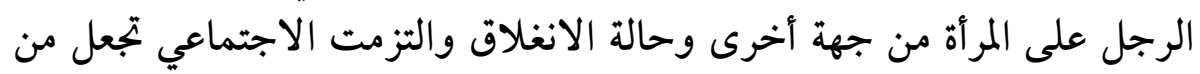

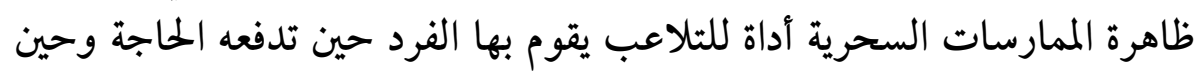
يعجز عن تحقيق غاية معينة بالوسائل التي يرضى عنها المجتمع (14).

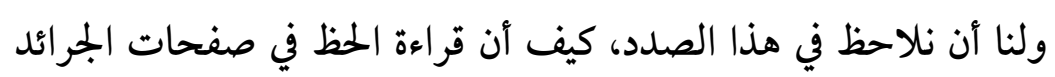

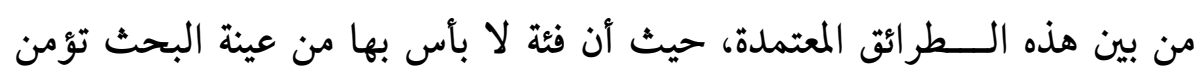

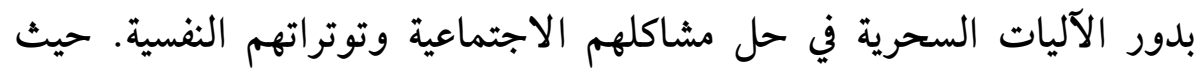

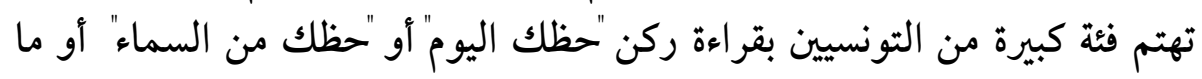

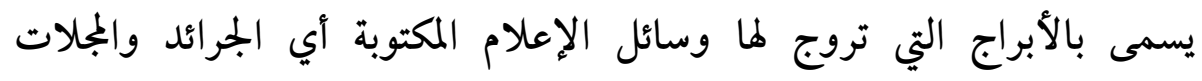

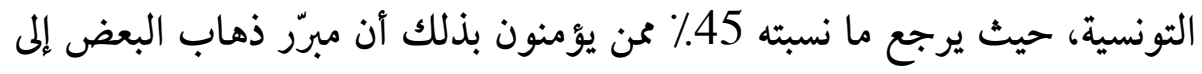

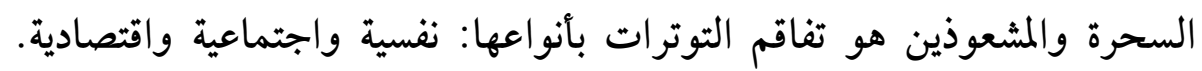

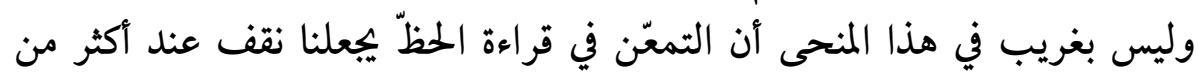

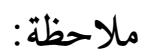

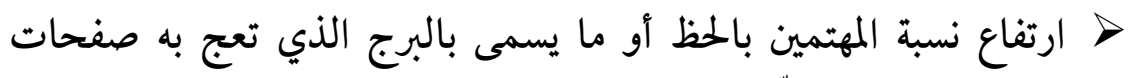

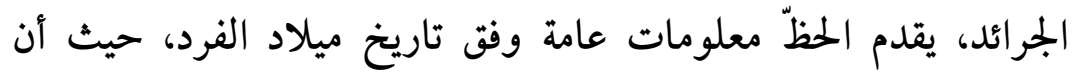

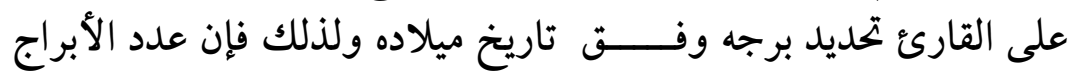

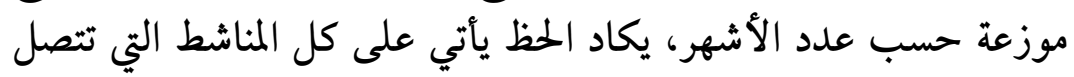

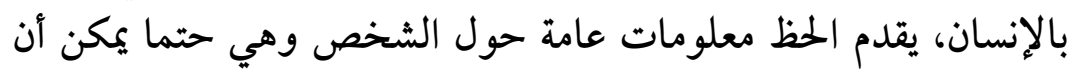

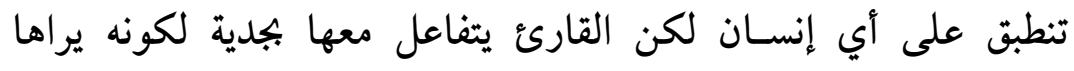

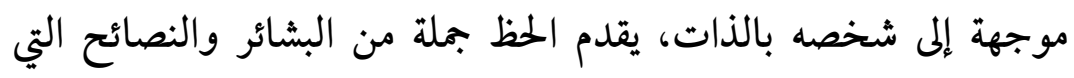
غالبا ما تسعد القارئ أو تحذره من أمر ما.

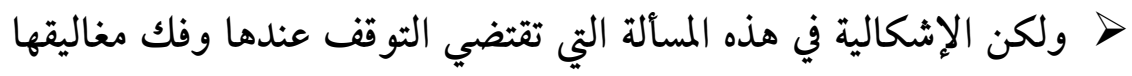

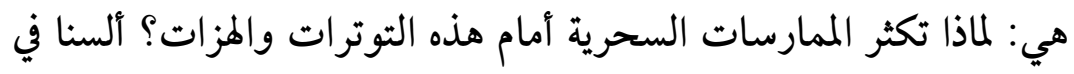

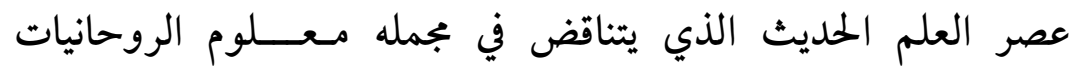


الصفراء وليس تلك التي هي وليدة العصر مثل علم النفس

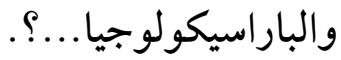

تبيّن لنا إثر تحليلنا للظاهرة السحرية في المجتمع التونسي، أن الانسان أمام

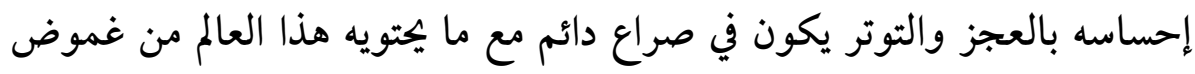

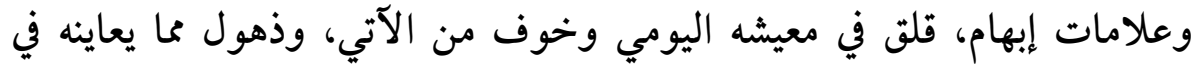

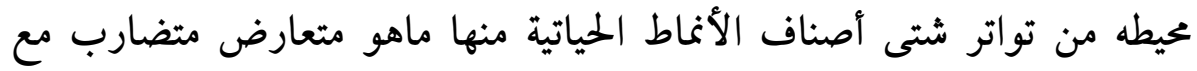

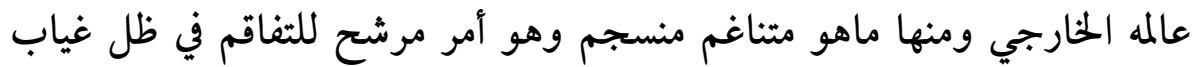

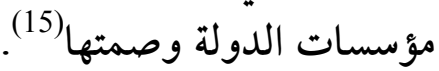

وبالتالي عدم اكتراثها بمشاغل الفاعلين وتطلعاتهم، وفي كل الحالات فإن الذات المهزومة والمثقلة بعبء هذه التوترات تسعى إلى ترميز همومها التي تصطدم التها

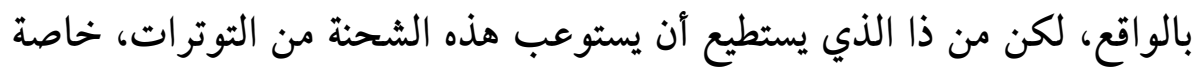

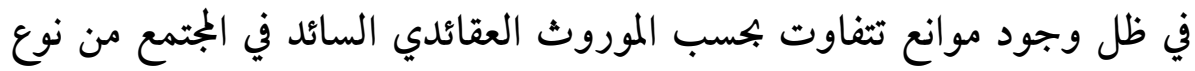

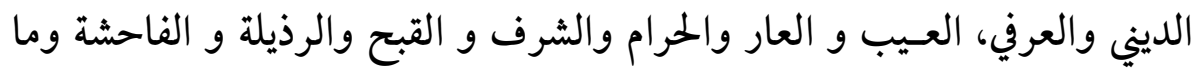

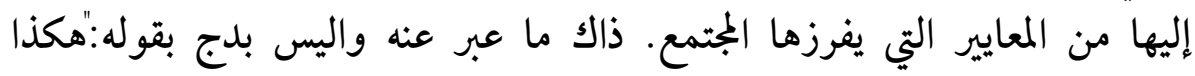

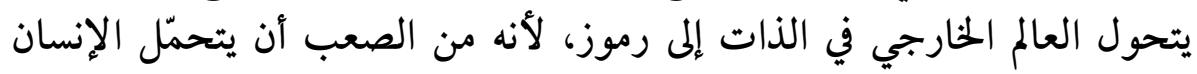

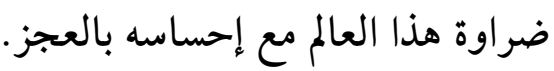

و في عملية الترميز للمدركات الحسية والنظرية، يتواصل الانسان مع النان

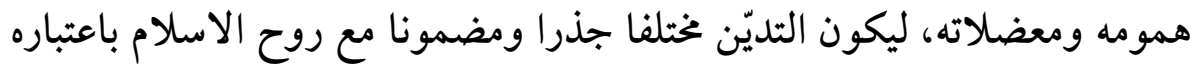

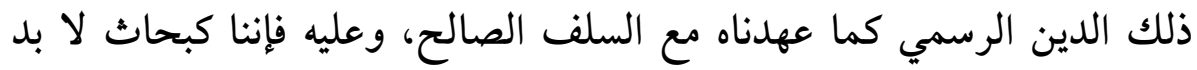

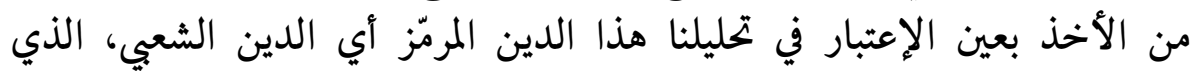
يتقاسم مع الممارسات السحرية والشعوذية الشيء الكثير (16).

وفي حدود هذا التحليل، هل نرجع انسياق المهزومين نفسانيا بهكم عبء

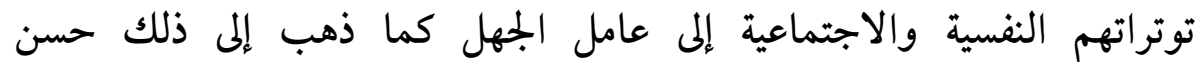
الشقرماني المتخصّص في دراسة الظاهرة السحرية في المجتمع المغربي من خلماعلمال 
قوله: " تجد معظم ضحايا الجهل يقرعون أبواب المشعوذين والدجالين، يطلبون

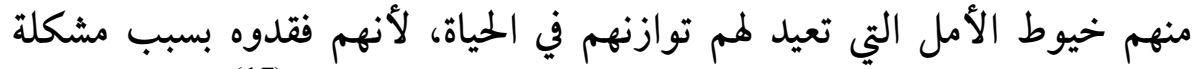

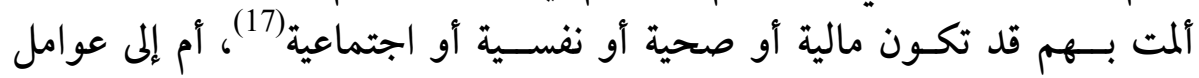

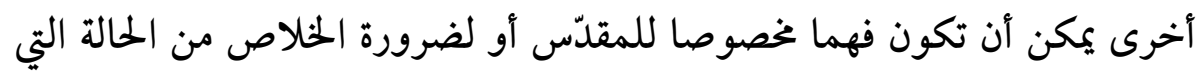

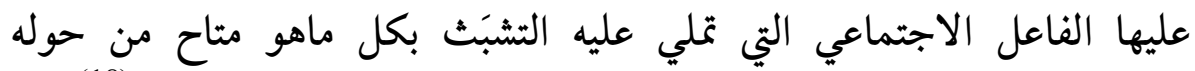
للخروج من حالته البائسة فيسود الاعتقاد في كرامات الأولياء و الصالحيه الحين (18).

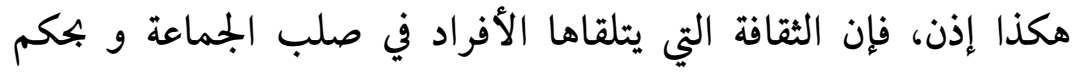

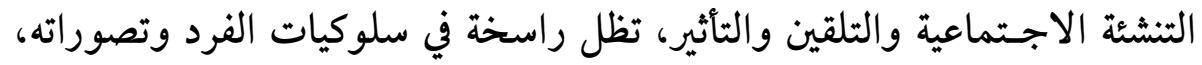

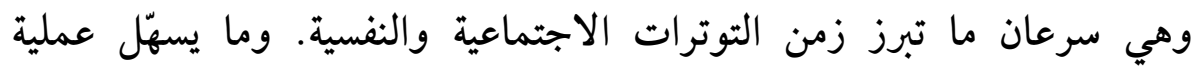

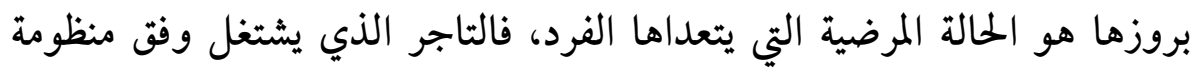

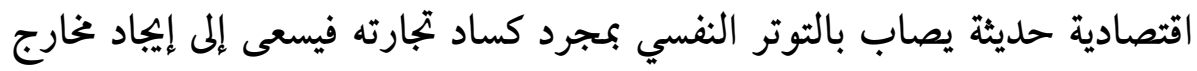

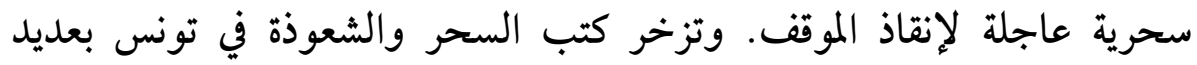

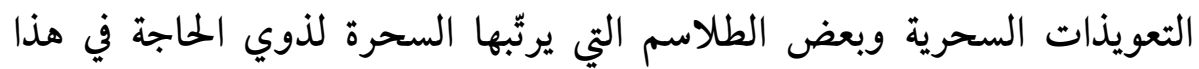
المجال (19)

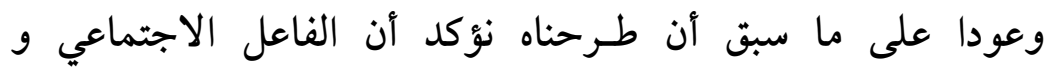

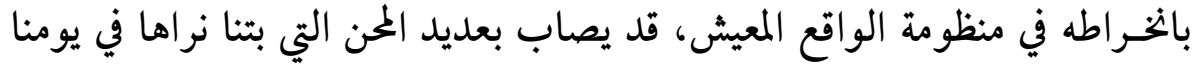

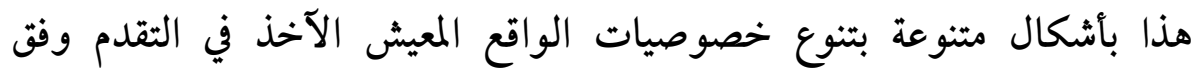

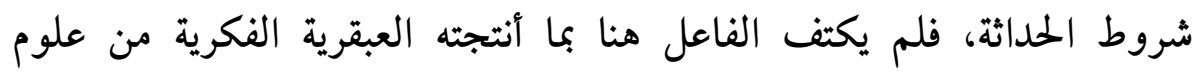

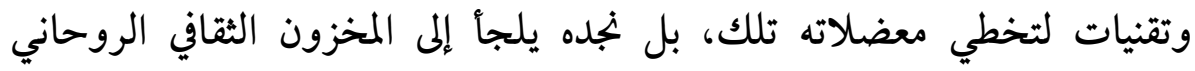
والذي منه السحر و الشعوذة.

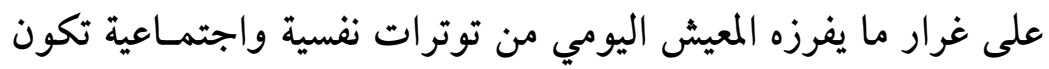

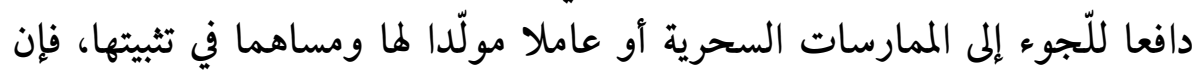

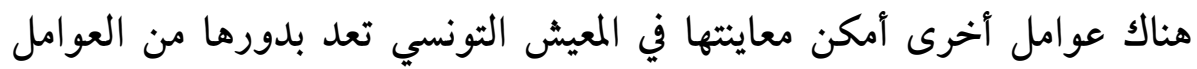

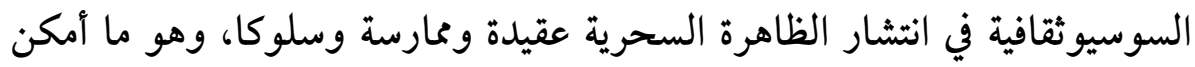
تبويبه في العنوان الفرعي الآتي: 
2.2 الممارسات السحرية من خلال معضلة المرض و البحث عن العلاج:

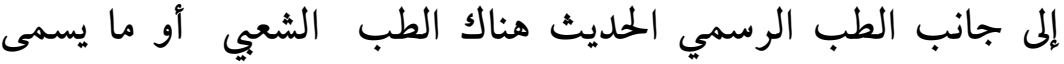

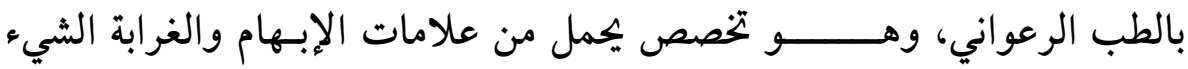

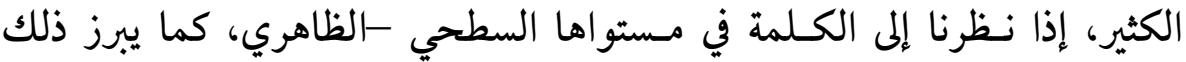
الملفوظ، فهو طب يعتمد على استخدام الحشائش و بعض طرائق العلاج التي

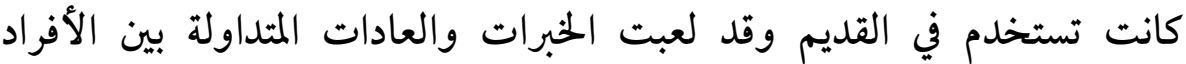

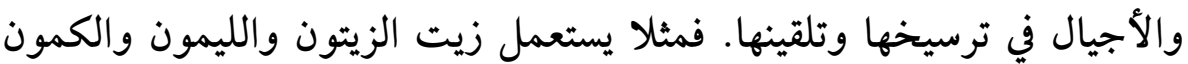

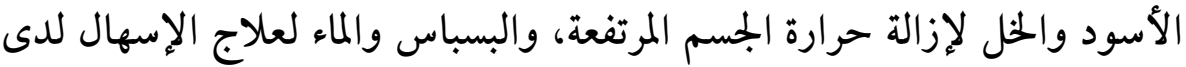

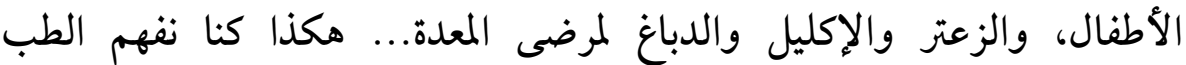

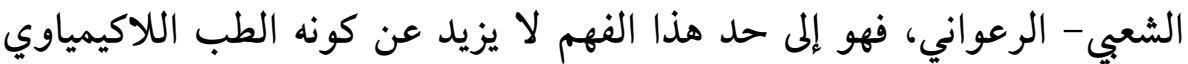
أي يعتمد على مواد بيولوجية وخبرات جماعية متداولة عبر الأجيال. لكن هل الطب الشعبي هو السحر و الشعوذة؟ هل من قواسم مشتركة

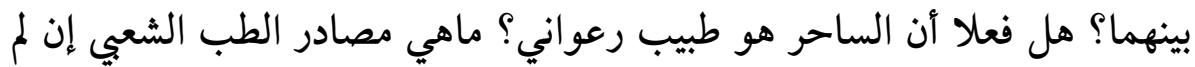

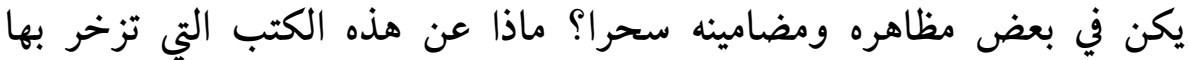

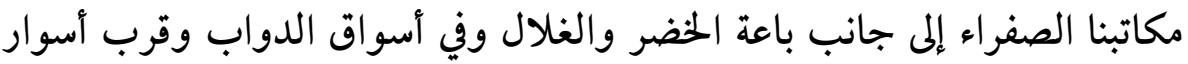

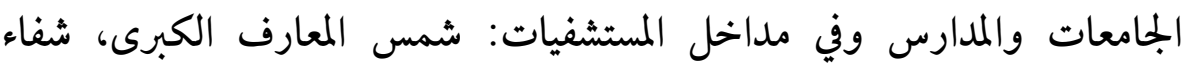

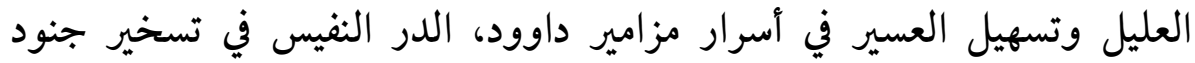

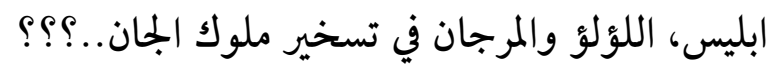

هذه إذا حيرة أولى أوردناها في شكل أسئلة تتصل بعالم السحر والطب الطب النبان

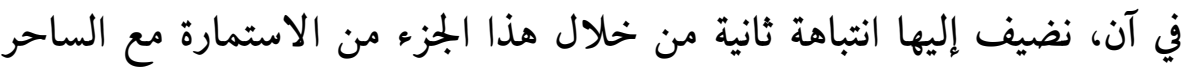

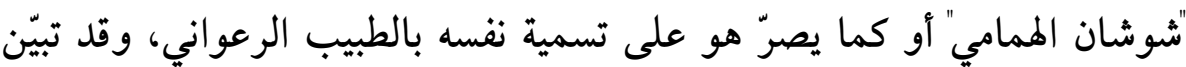

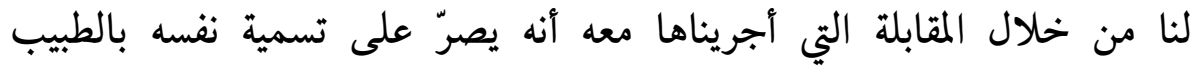

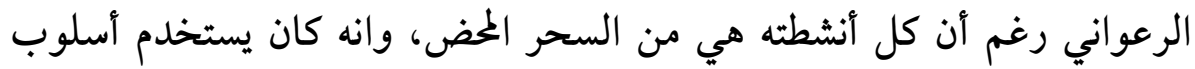

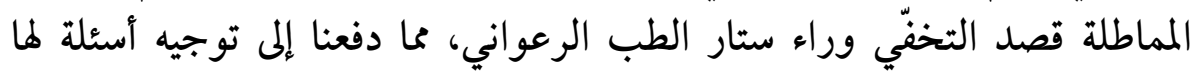


صلة بالسحر ووقتها يقرّ بشطارته في السحر ومن جملة ما صرّح به في هذا السياق نذكر:

"نعم، أنا أداوي الأمراض بأنواعها مثل السرطان والحجر في الكلى والمرارة... أنا

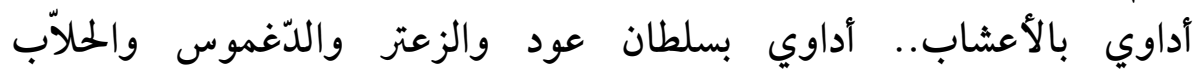

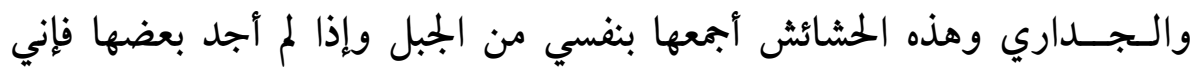
آتي بها من مناطق أخرى (20).

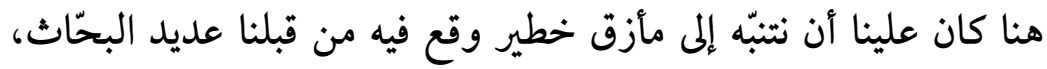

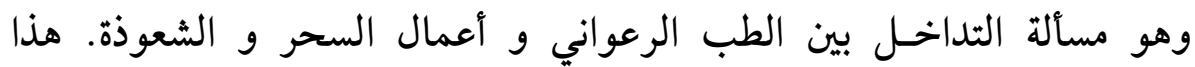

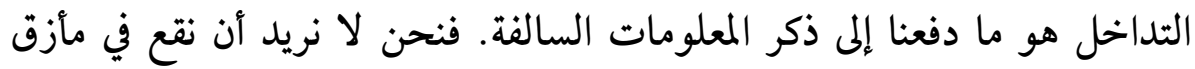

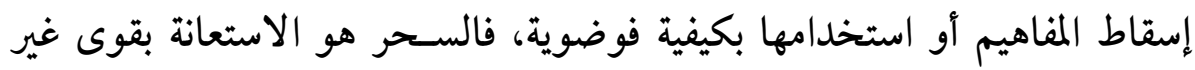

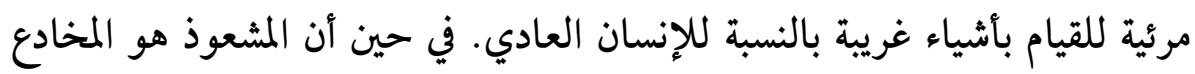

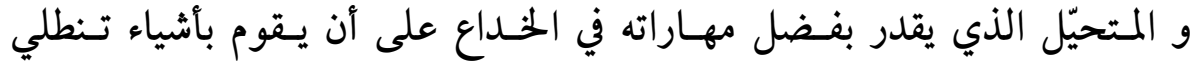
على الفـــد فتكون بالنسبة له أثــبه بالسحر و الخارق.

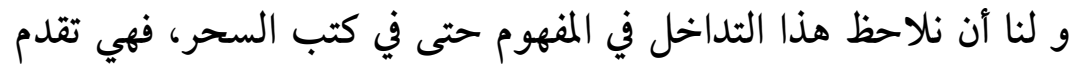

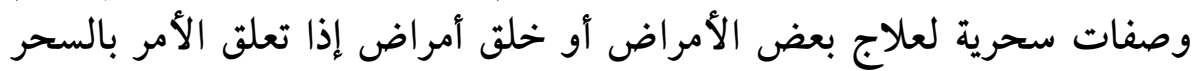

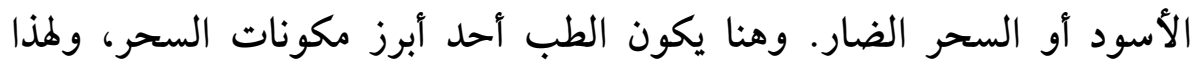

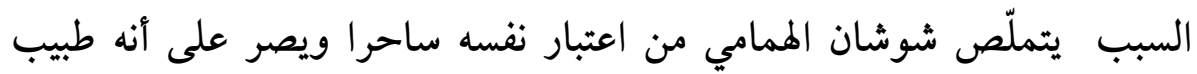

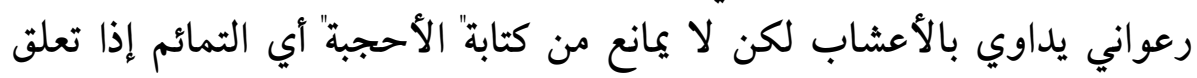

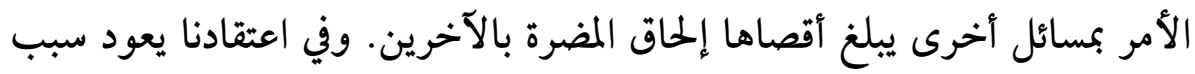

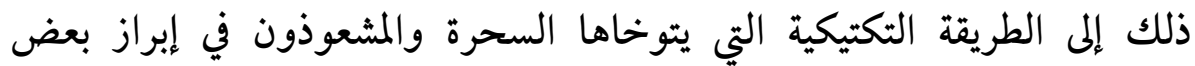

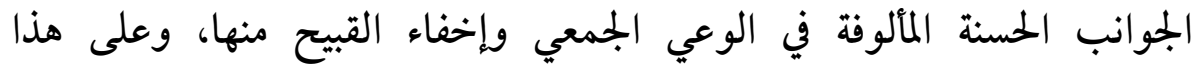

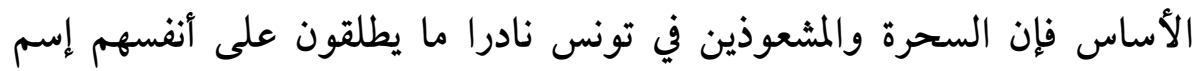

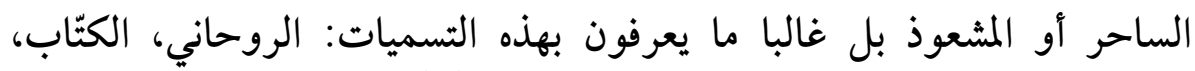

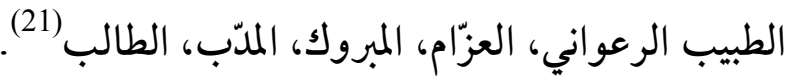




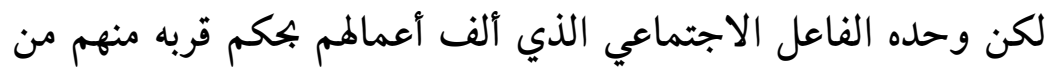

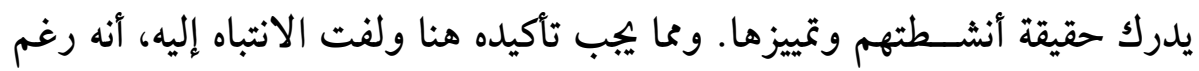

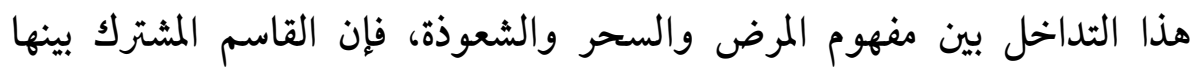

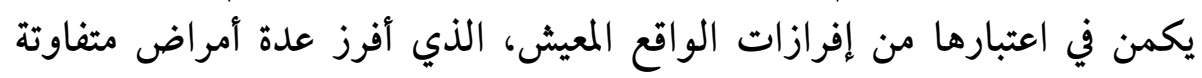

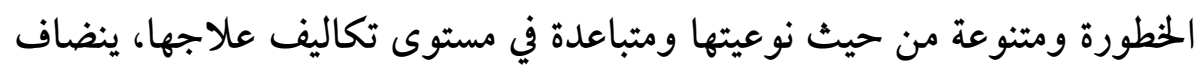

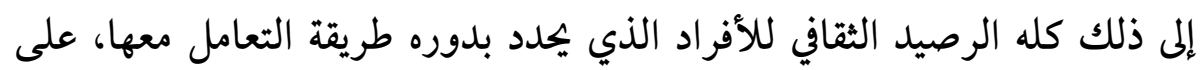

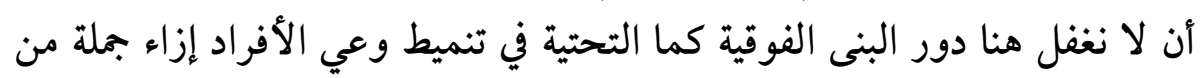
القضايا داخل المجتمع وخاصة منها العامل الديني والاقتصادي واليني في السياسي.

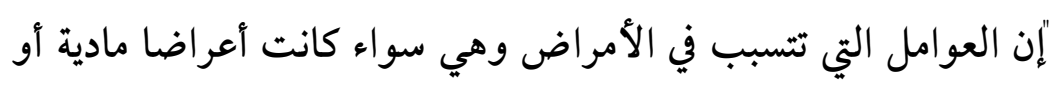
حالات نفسية فإنها تعود إلى طائفتين من الأسباب:

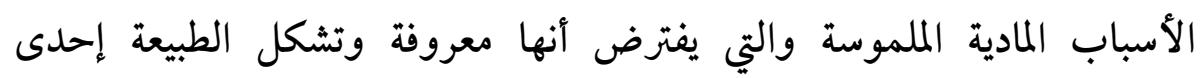
مصادرها الرئيسية.

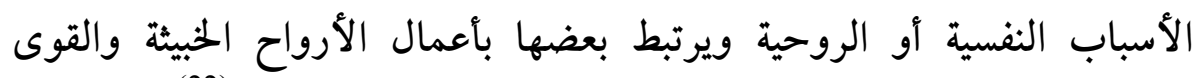
الشريـرة والبعض الآخر بغضب الله ونقمة أحد الأسلاف المقدسين (22).

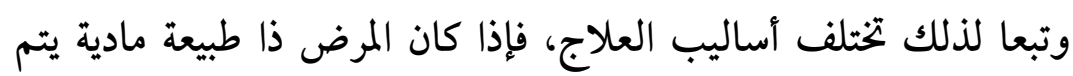

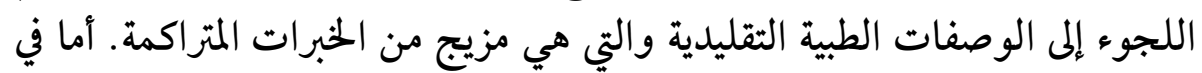

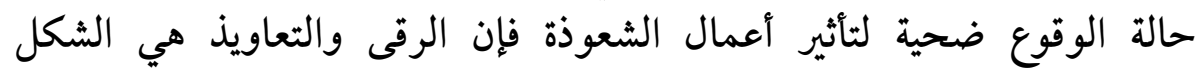

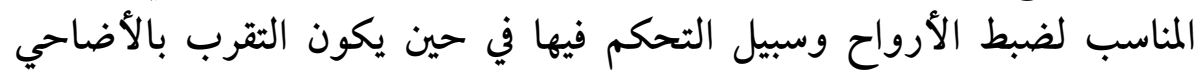

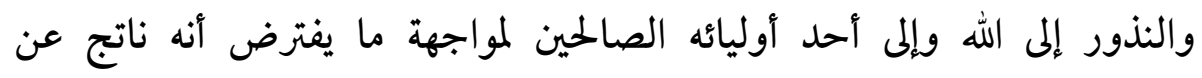

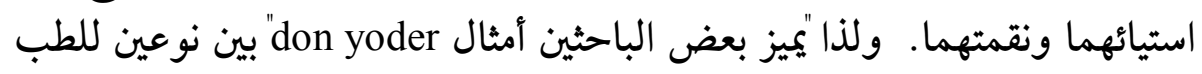

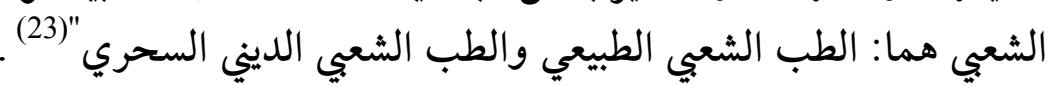

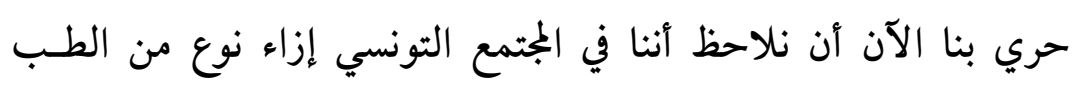

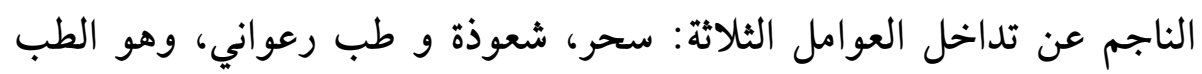

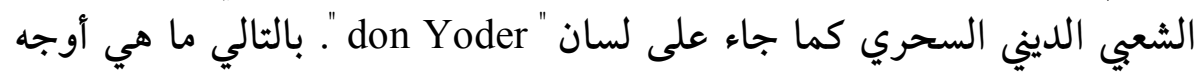


التقارب بين المرض والسحر في المجتمع التونسي من خلال ما توصلنا إليه في

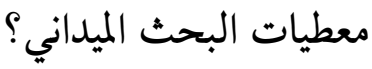

يعتبر المرض حالة اجتماعية مرضية تصيب الإنسان، ولكل مرض- وفيق

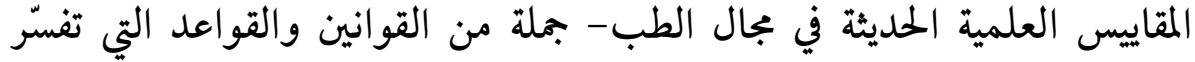

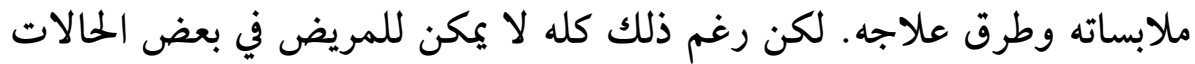

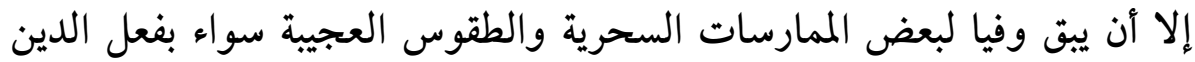

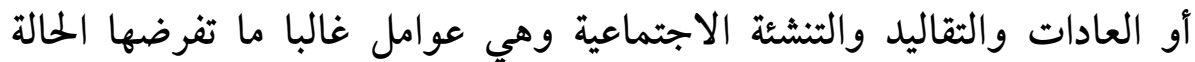

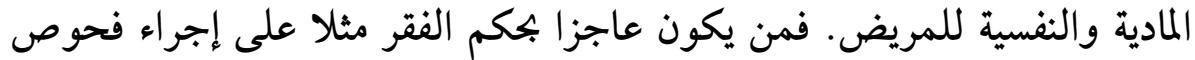

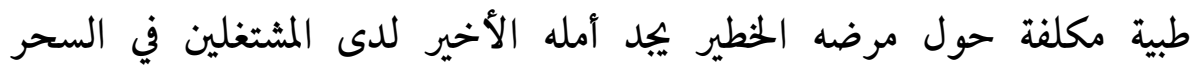

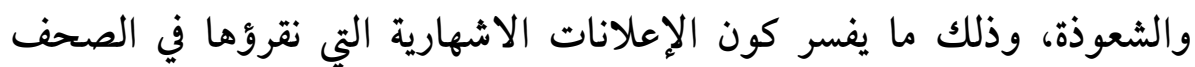

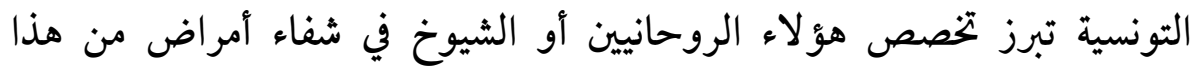

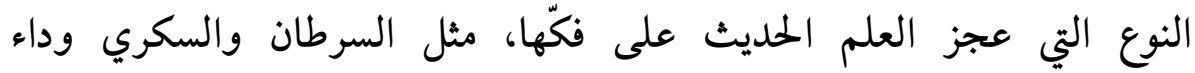

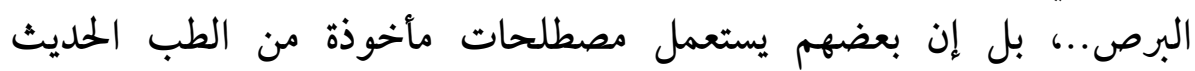

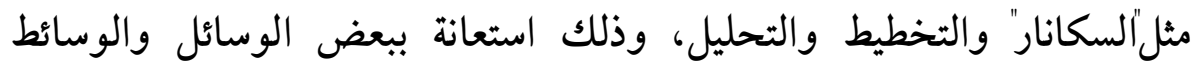

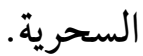

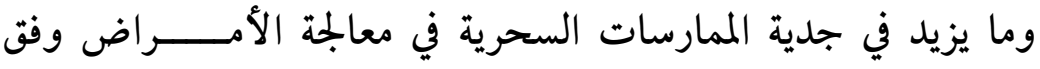

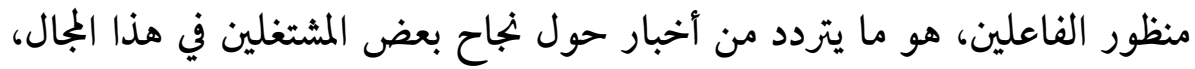

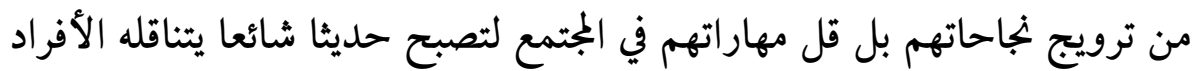

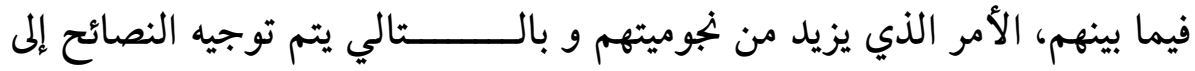
بعض المرضى بزيارة سيدي فلان ونتيجة الشفاء مضمونة كليا.

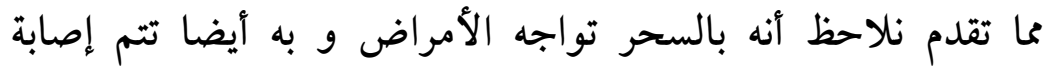

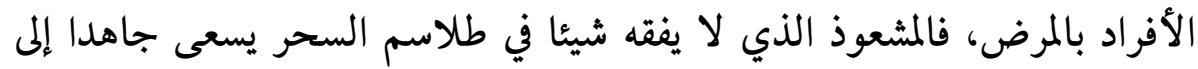

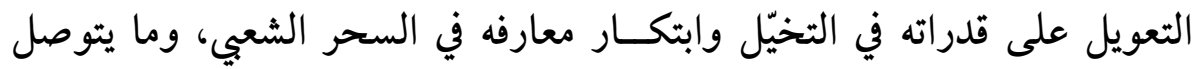

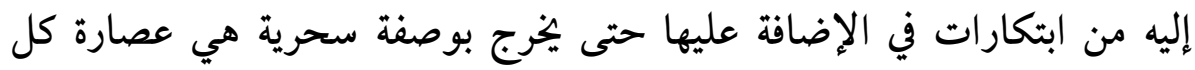

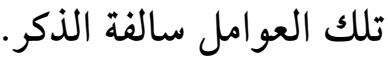


لا يزال سكان شمال إفريقيا أي بلاد المغرب العربي، ومنهم تونس، يخلطون بين

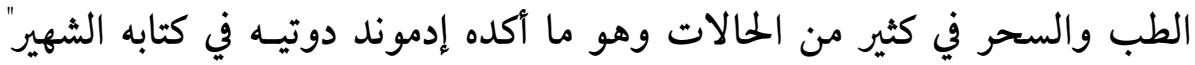

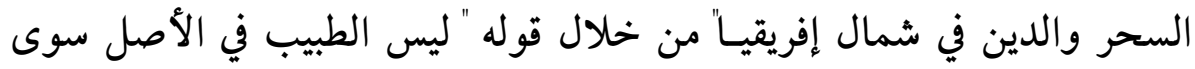

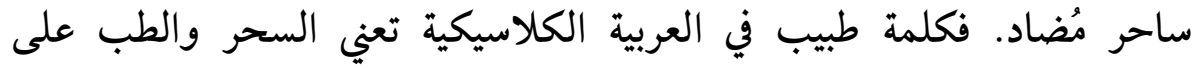

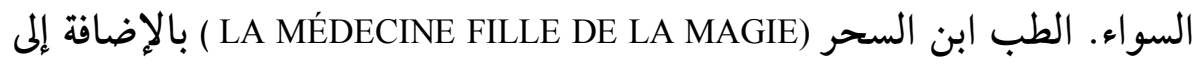

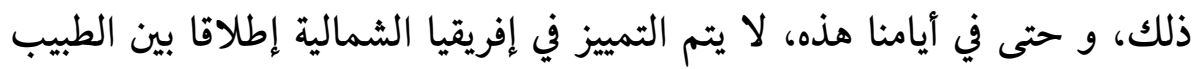

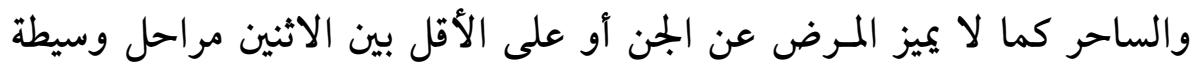
غير محسوسة (24).

وللتدليل عل أوجه التقارب بين الممارسات السحرية ( السحر والدجل

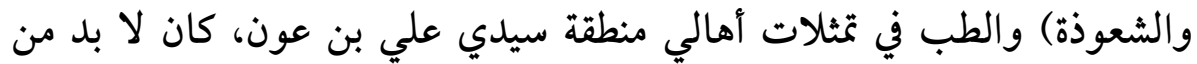

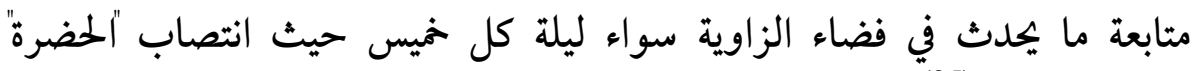

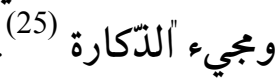

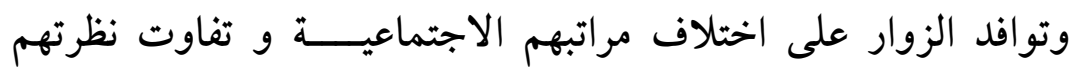

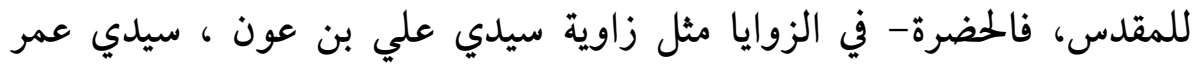

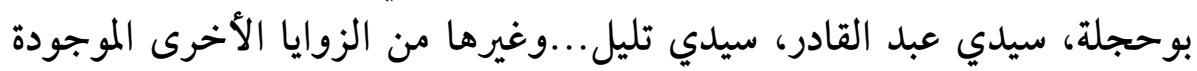

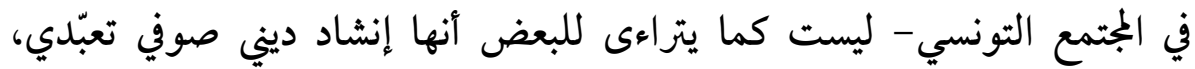

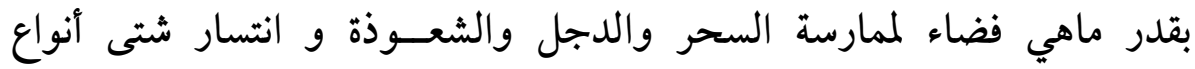

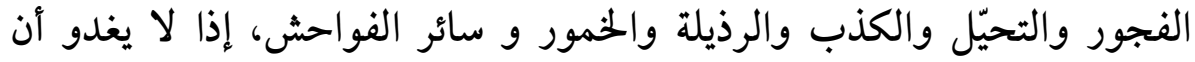

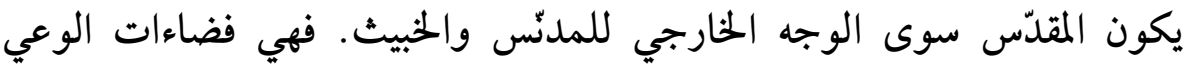

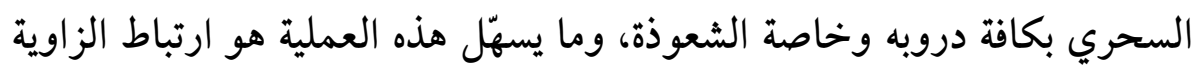

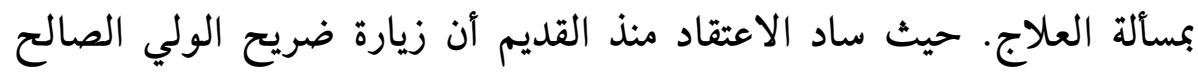

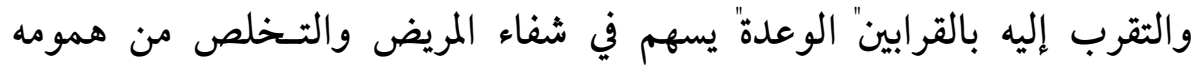

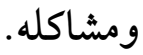

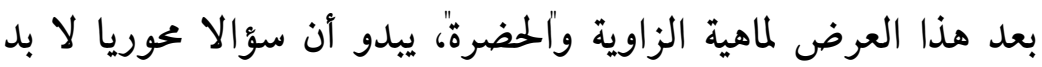

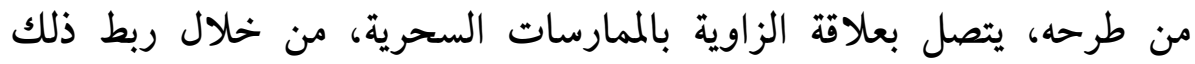


بمشكلة المرض و التداوي. إذن السؤال المحوري الذي يمكن طرحه في هذا السياق

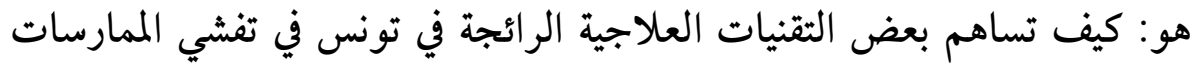

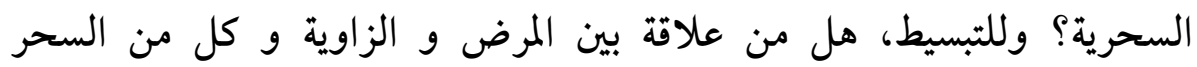

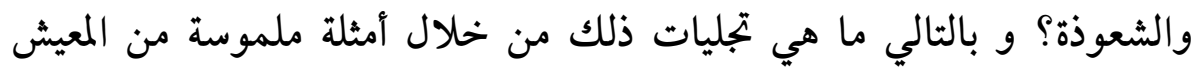

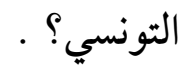

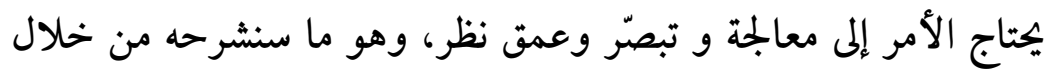

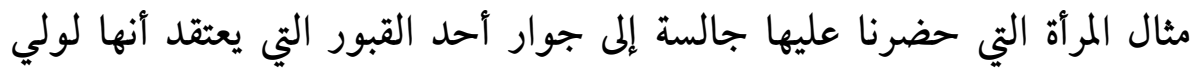

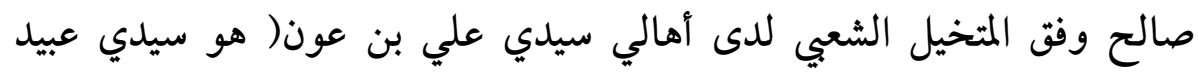

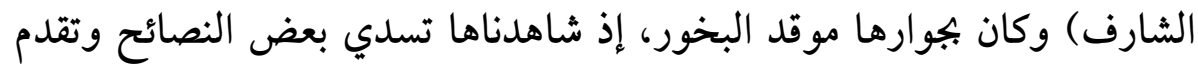

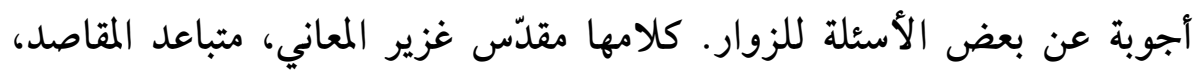

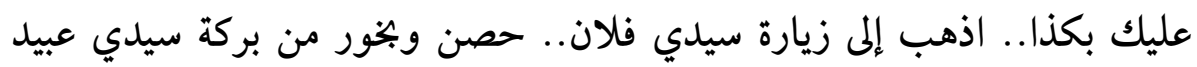

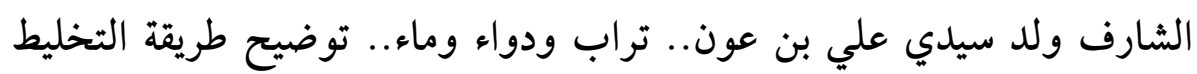
وأوقات الفعل..والدفع على قدر حال الزائر.

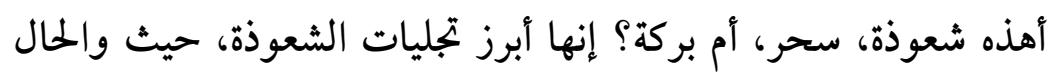

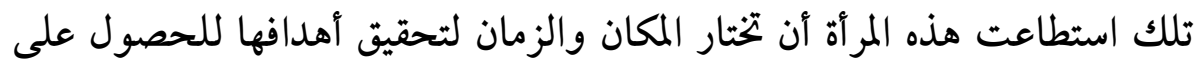

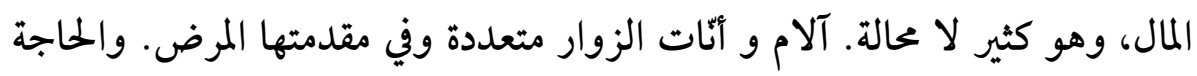

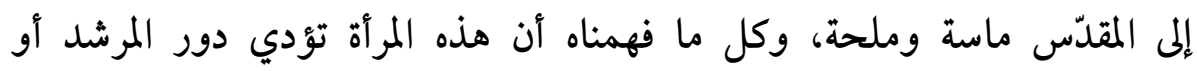

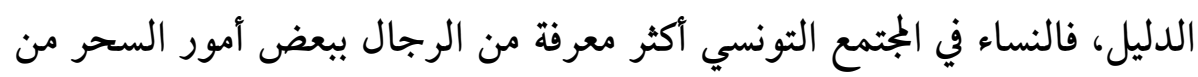

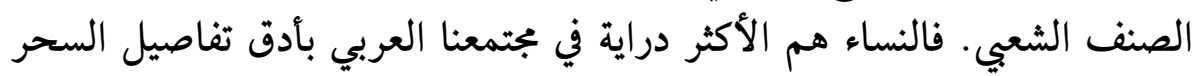

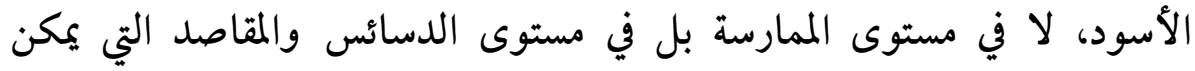

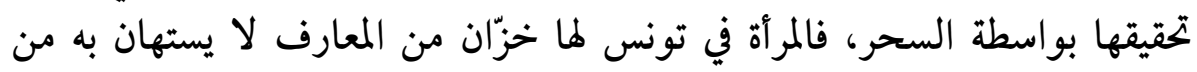

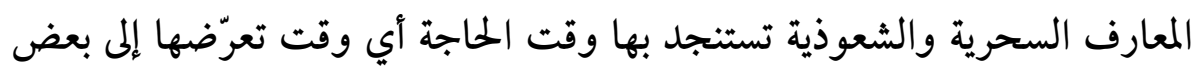

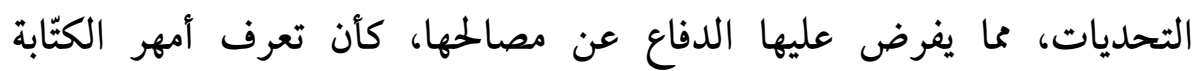

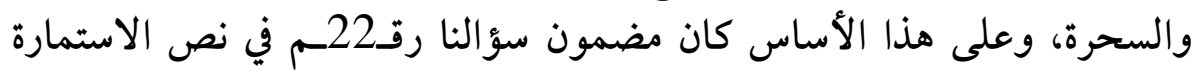

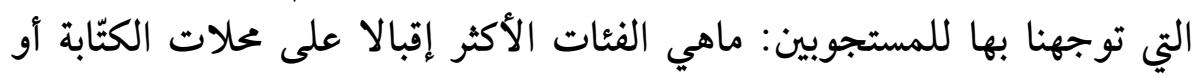




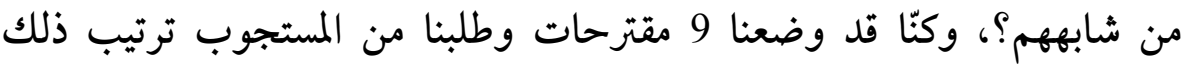

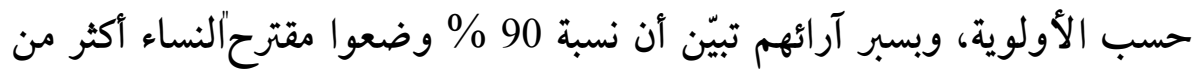

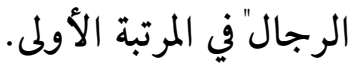

وليس قولنا أن المرأة أكثر إقبالا على السحر والشعوذة، مقارنة بالرجل

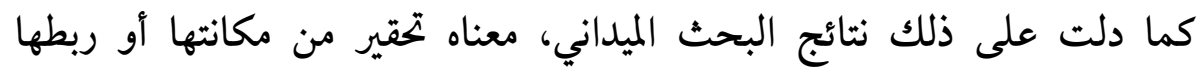

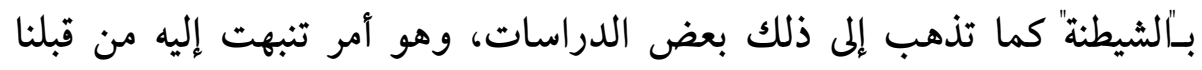

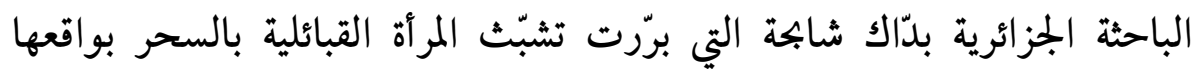

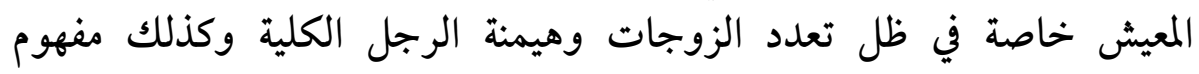

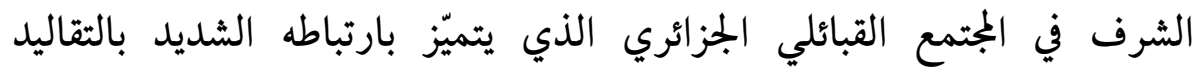

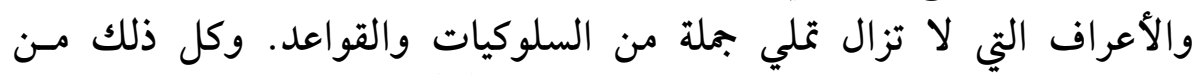

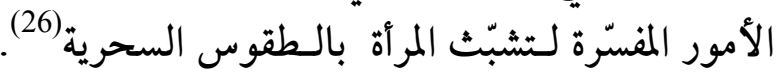

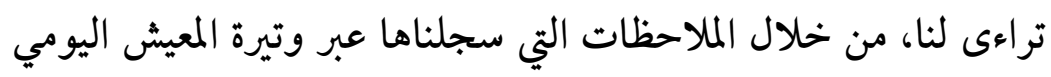

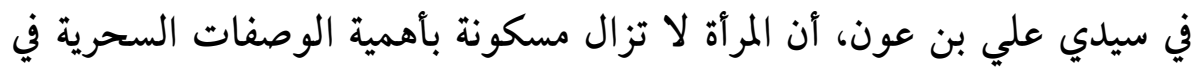

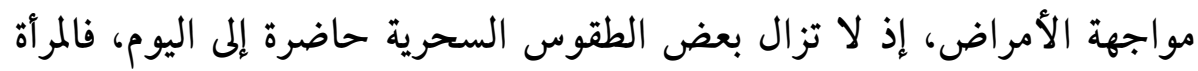

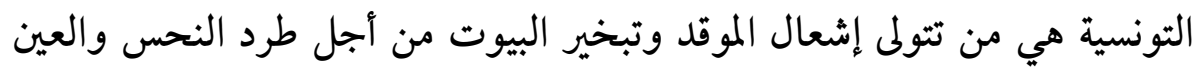

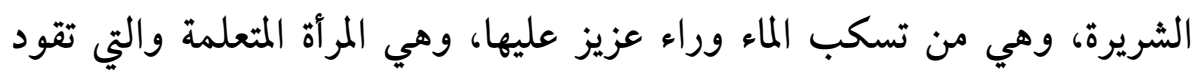

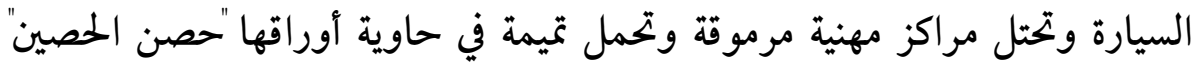

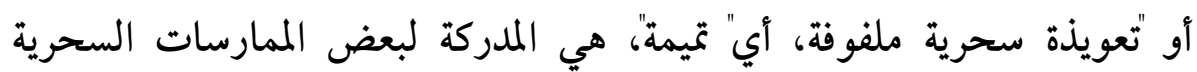

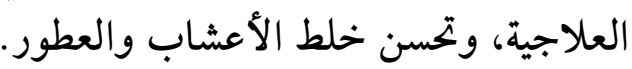

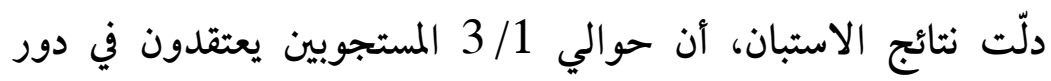

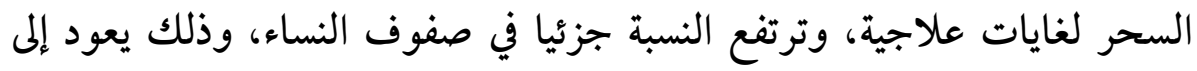

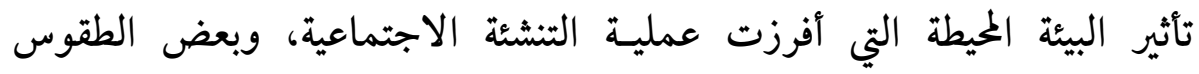

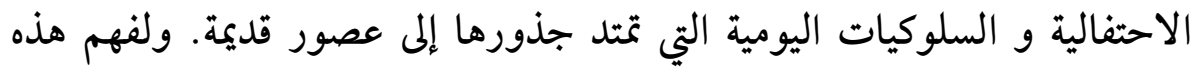

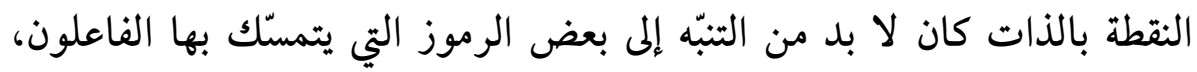

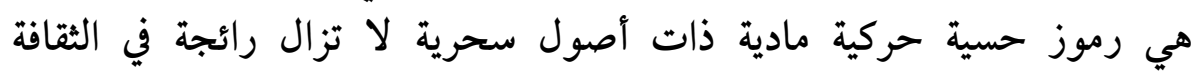


التونسية ونعتبرها من الدوافع المساهمة في تفشي الاعتقاد بالروحانيات، والبحث الإثل

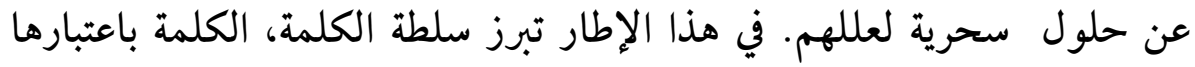

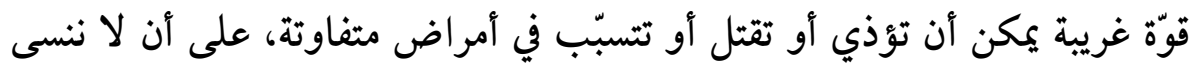

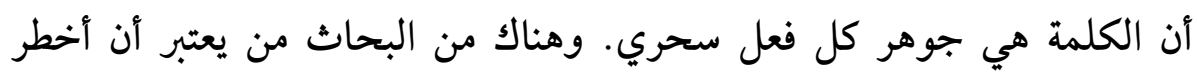

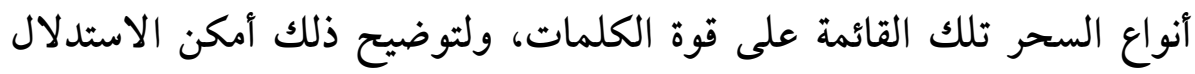

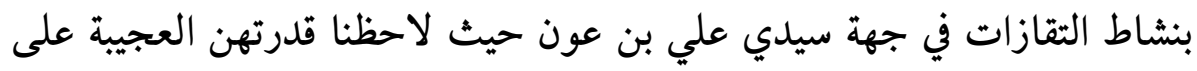

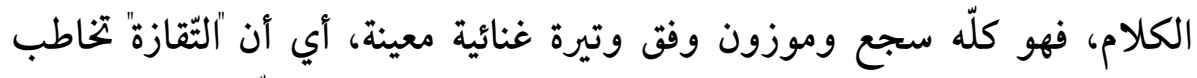

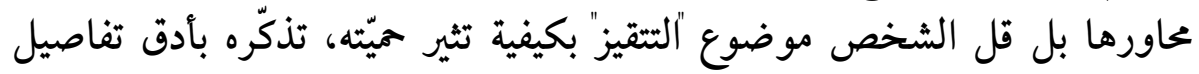
ماضيه وحاضره ومستقبله.

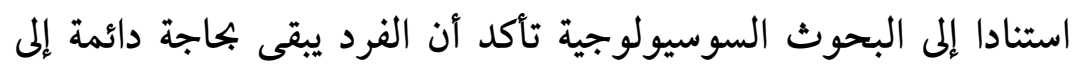

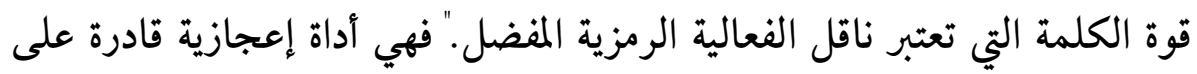

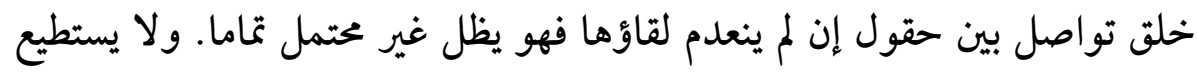

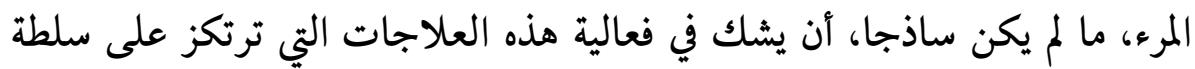

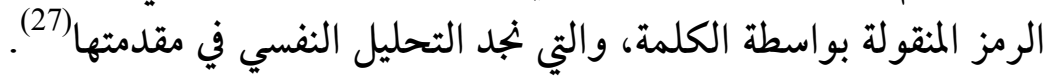

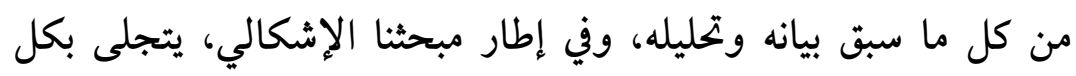

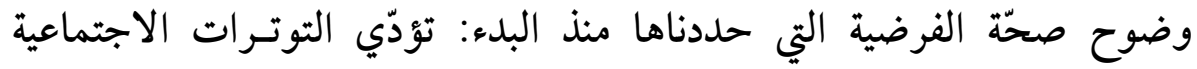

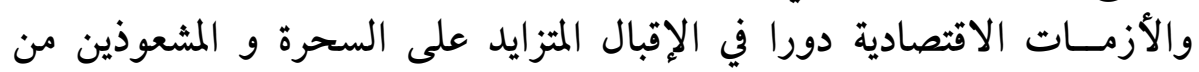

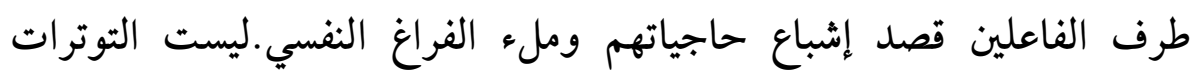

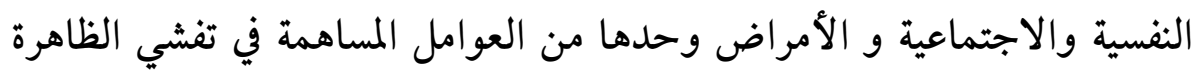

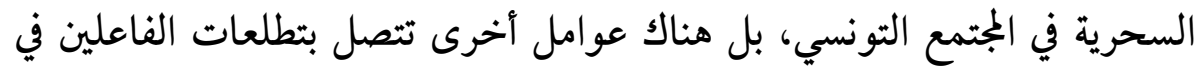
الواقع المعيش وهو ما أمكن تبويبه في المشهد التالي: المئي 
3.2 السحر والشعوذة من خلال تطلعات الفاعلين إلى تحقيق التغير و الحراك الاجتماعيـين:

من المعروف أن هناك عدة وصفات سحرية تستعمل لأغراض مختلفة منها" توسيع الرزق، زيادة الفهم، تقوية الذاكرة، التوسل لدى أصحاب ولمعاب السلطة، العثور

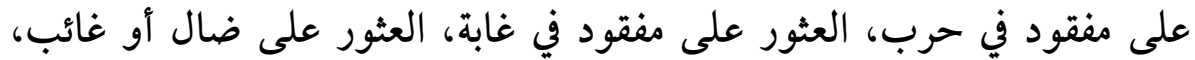

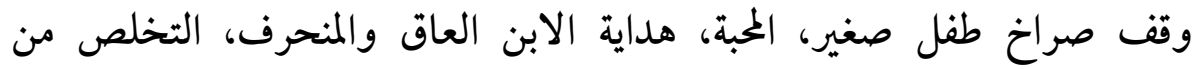

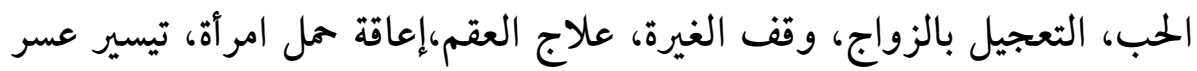

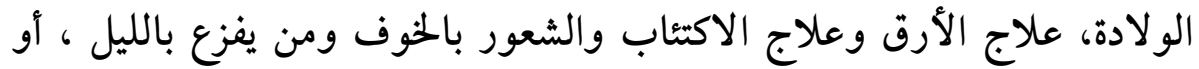

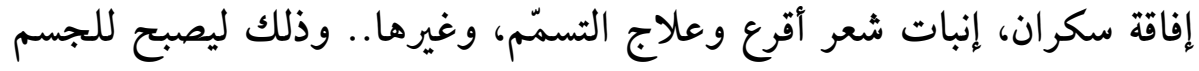

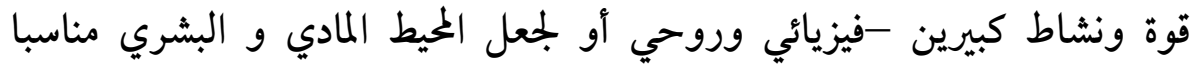
للمسحور حسب الناس (28).

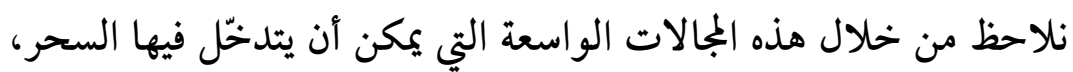

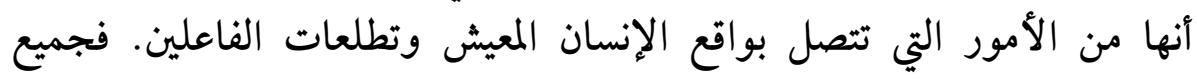

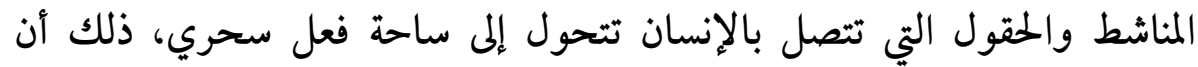
وتيرة الحياة المتسارعة تدفع الفاعلين إلى توخي شتئى السبل المتاحة لتحول لتحقيق

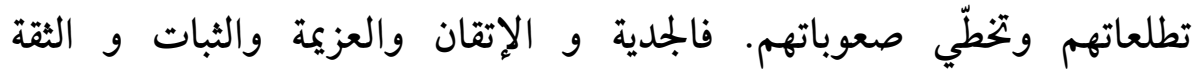

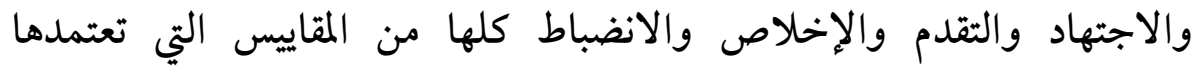

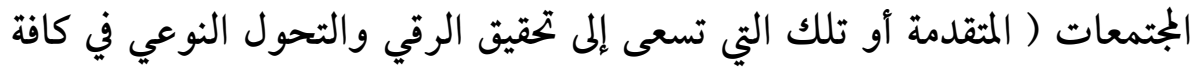

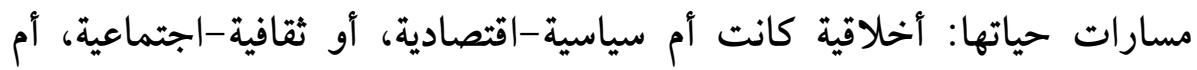
علمية- تقنية) لتحقيق رقيّها ونهضتها.

على هذا النحو، يُرسم طريق الحداثة كما سبق أن رسمته الشعوب التي

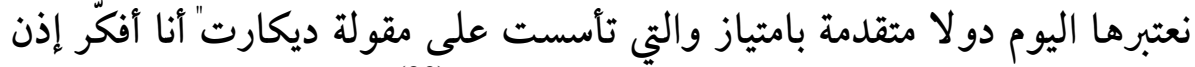

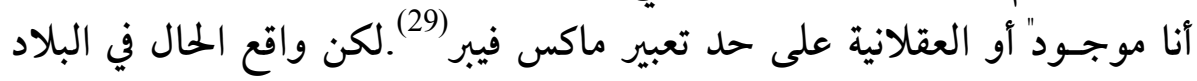

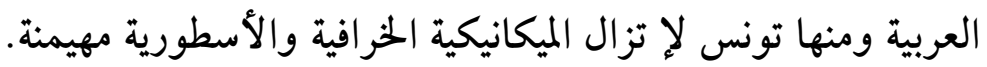




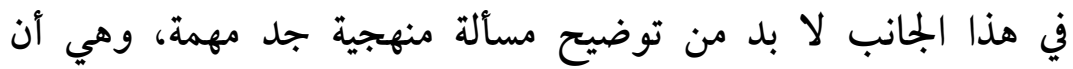

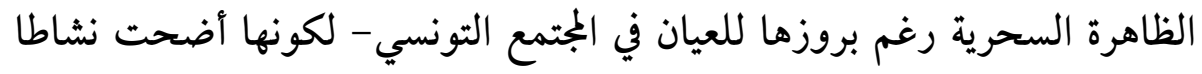

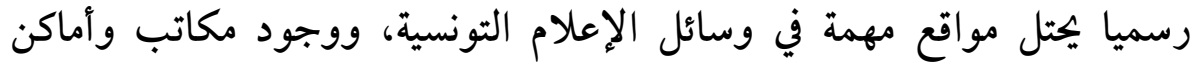

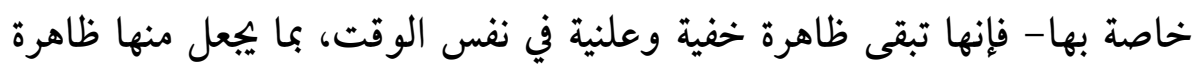

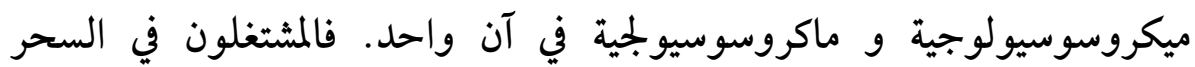

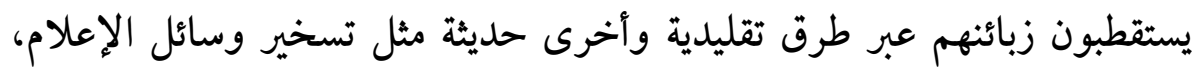

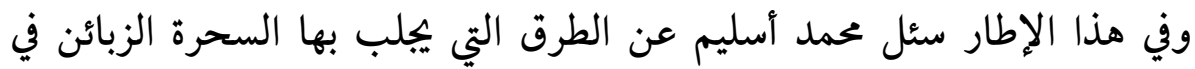

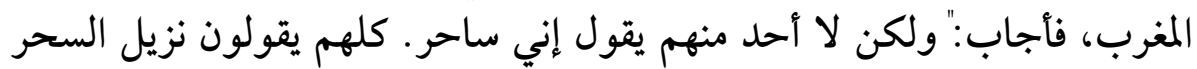

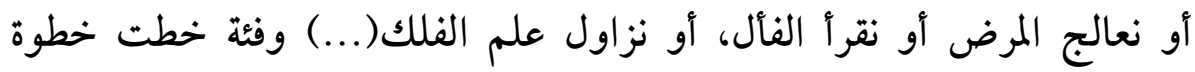

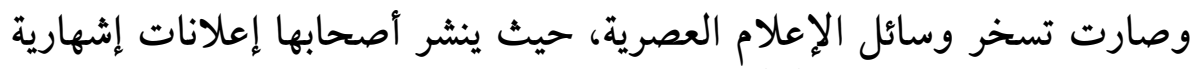

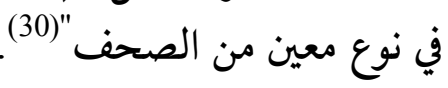

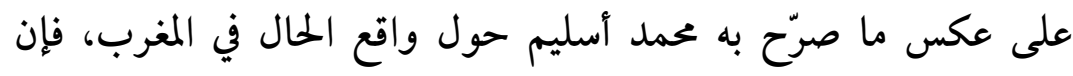

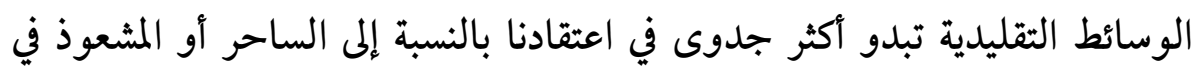

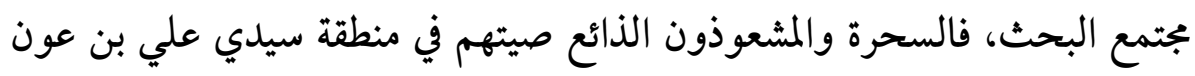

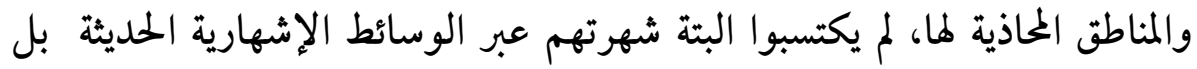

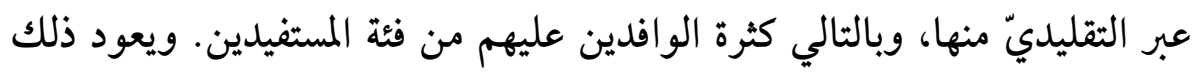

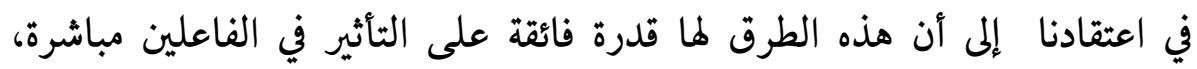

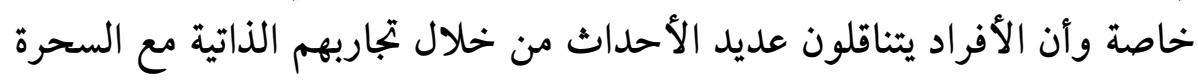

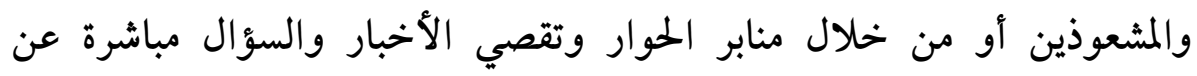

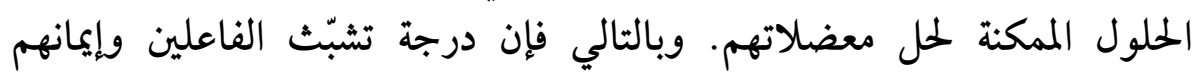

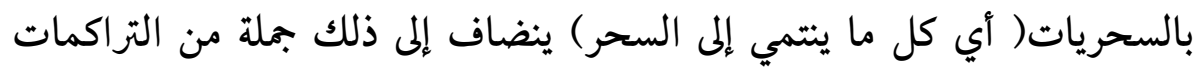

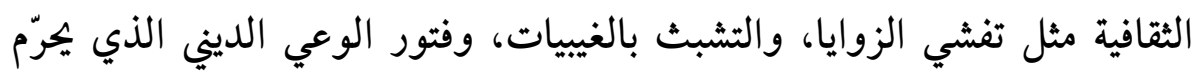

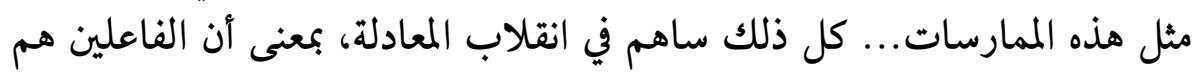
من يخلقون شهرة الساحر أو المشعوذ على حد السواء. 


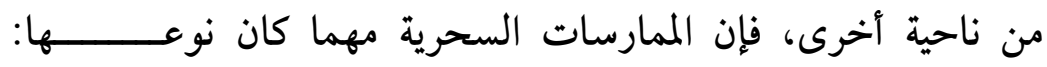

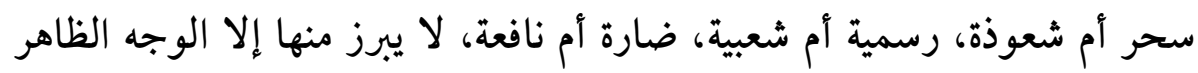

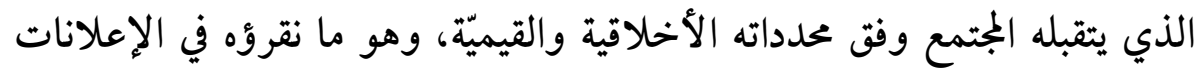

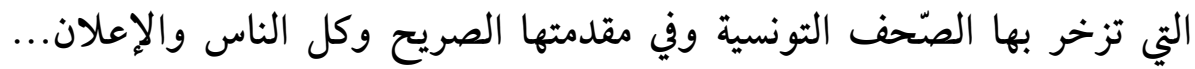

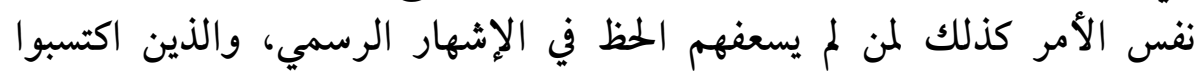

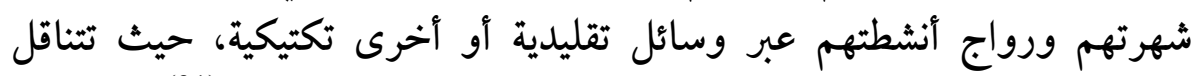

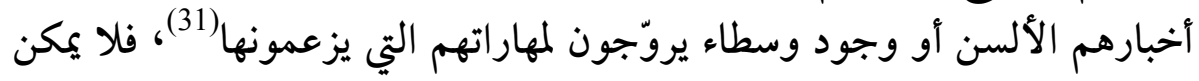

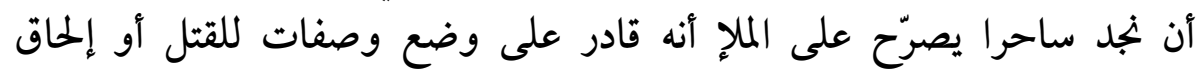

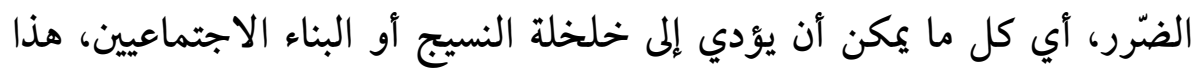

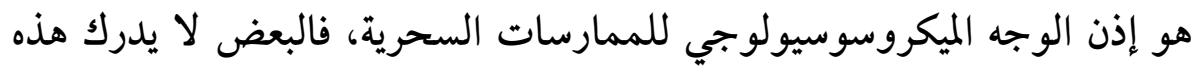

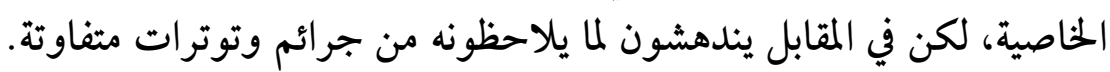


جلول رق2هم: الأنشطة التي يتعاطاها السحرة والمشعوذون في سيدي علي بن عون (32)

\begin{tabular}{|c|c|c|c|c|}
\hline \multicolumn{4}{|c|}{ الإجابة } & \multirow[t]{3}{*}{ الأنشطة } \\
\hline \multicolumn{2}{|c|}{ لا } & \multicolumn{2}{|c|}{ نعم } & \\
\hline النسبة \% & التكرار & النسبة \% & التكرار & \\
\hline 5 & 1 & 95 & 19 & علاج الأمراض \\
\hline 5 & 1 & 95 & 19 & فكَّ السحر \\
\hline 30 & 6 & 70 & 14 & تخليص الناس من الجان \\
\hline 20 & 4 & 80 & 16 & فتح باب الرزق \\
\hline 25 & 5 & 75 & 15 & قراءة البرج \\
\hline 20 & 4 & 80 & 16 & الإصلاح بين الزوجين \\
\hline
\end{tabular}

لكن ذلك لا ينفي أن مزاعم السحرة والمشعوذين كلها خرافات ووهم.

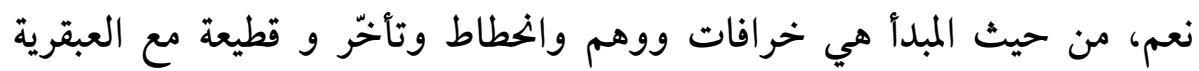

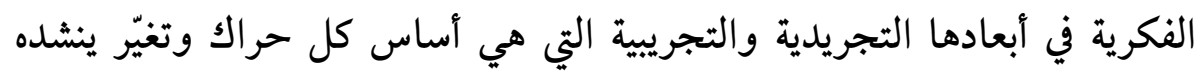

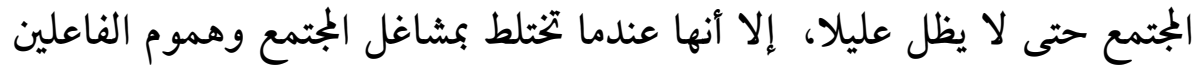


وتطلعاتهم ترتقي إلى درجة الفعل الظاهر البيّن الذي له دلالاته ومعانيه، مثل

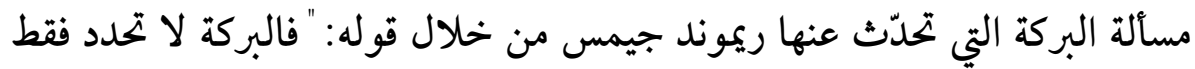

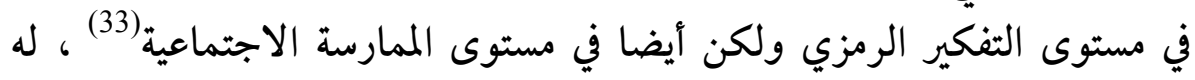

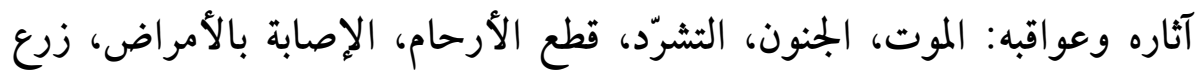

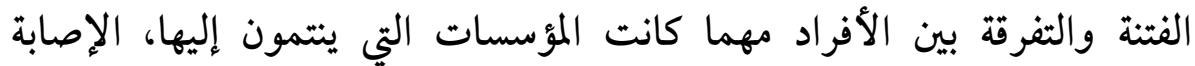

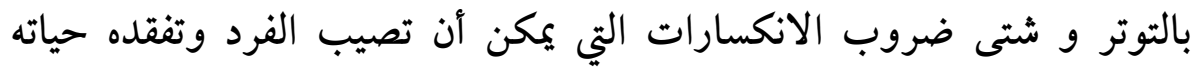

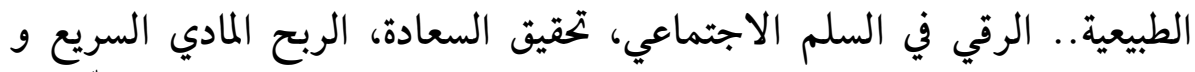

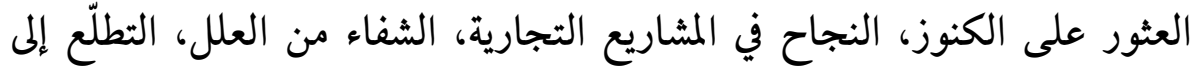

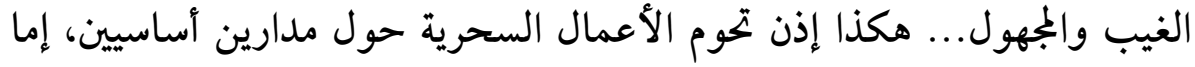

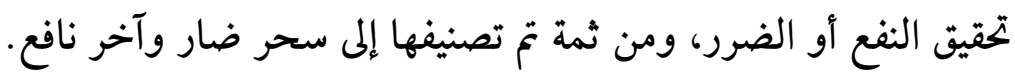
نحن إذن أمام ثنائية حضارية-سوسيولوجية من الظاهرة السحرية

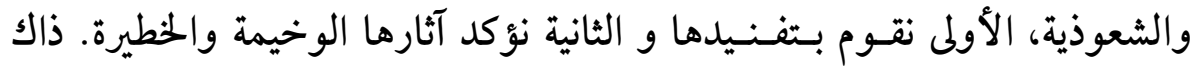

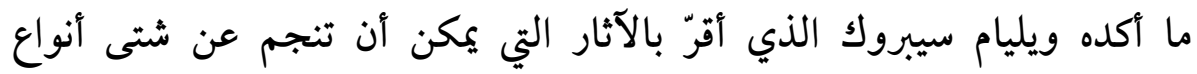

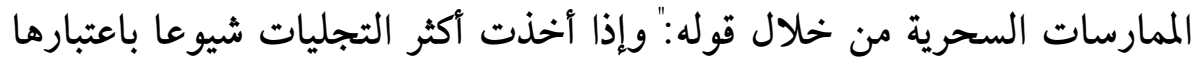

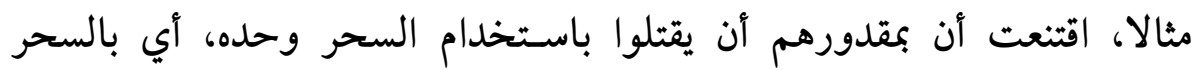

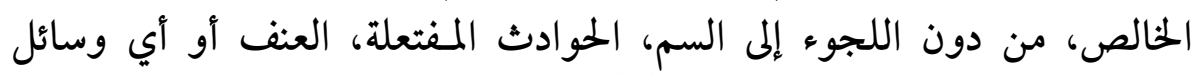
مساعدة كيميائية-فيزيائية مهما كانت (34).

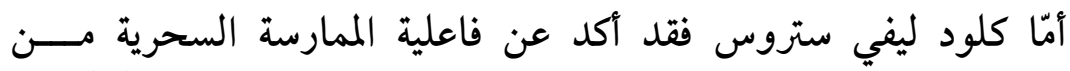

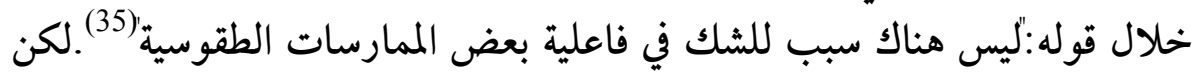

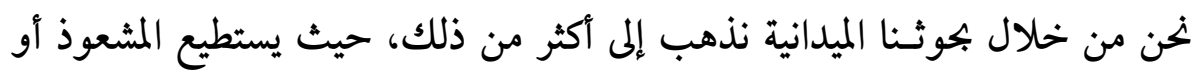

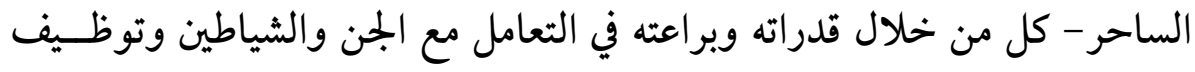

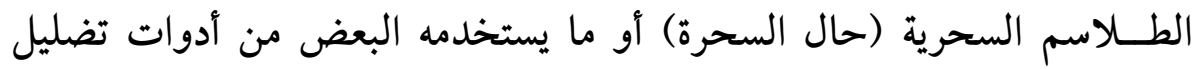

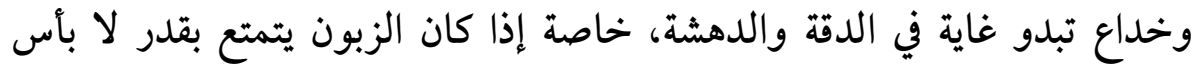

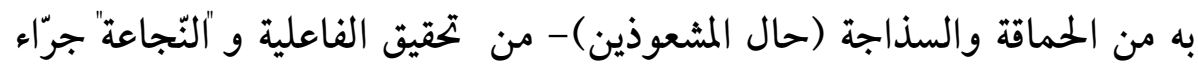

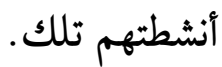




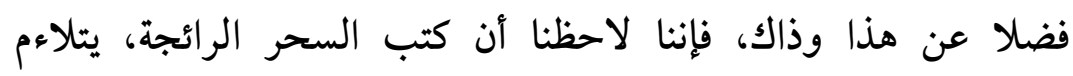

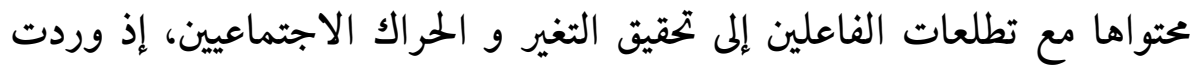

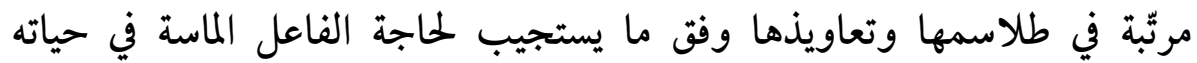

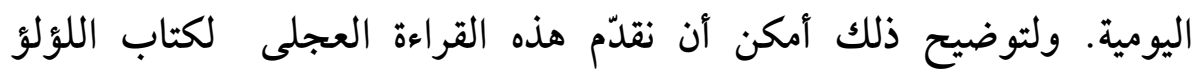

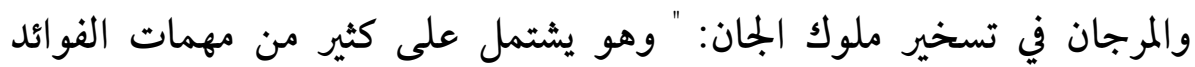

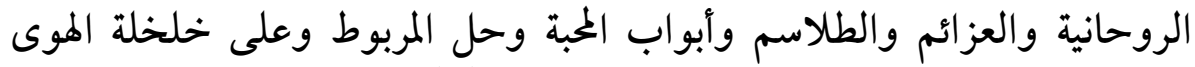
الكبرى الصحيحة المجربة وخلاف ذلك والطان واله أعلم (36).

$$
\text { وهذه أبرز أبوابه وفوائده حلى حد قولى كابه كاتبه: }
$$

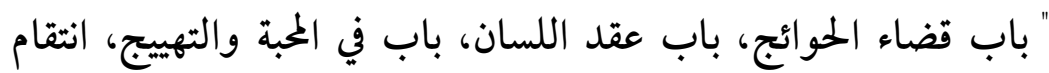

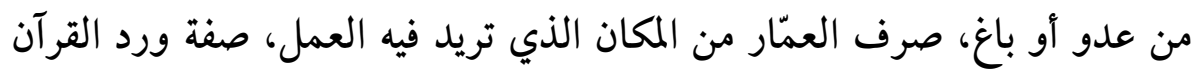

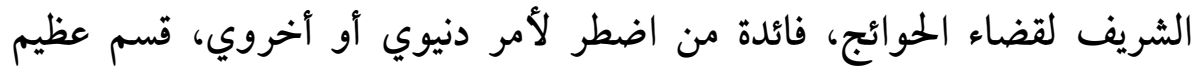

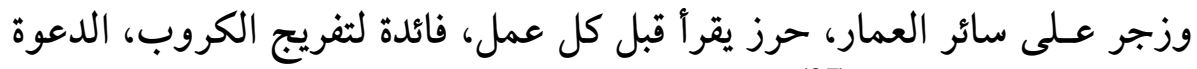

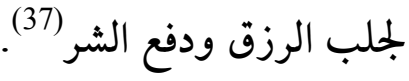

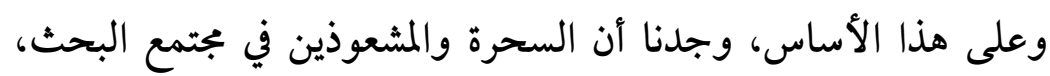

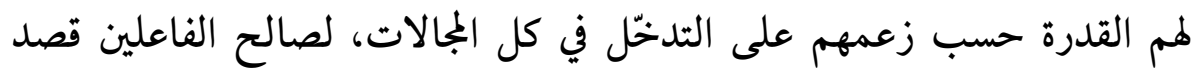

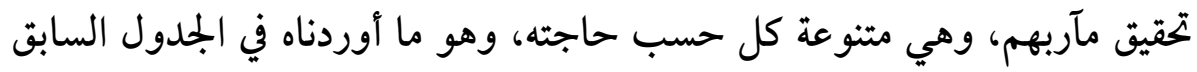
الذي يبيّن الأنشطة التي يتعاطونها وفت ما دئت دئت عليه نتائج الاستبيان الخاص بالمشتغلين في السحر. 


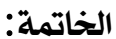

إن دراستنا ليست حصرا جامعا مانعا لكل ما يتّصل بالظاهرة السحرية

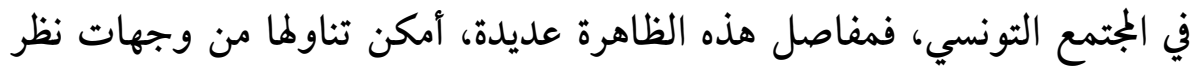

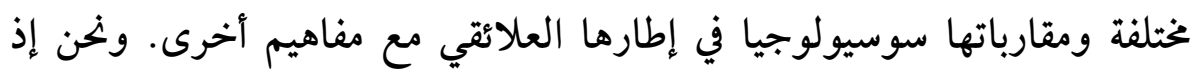

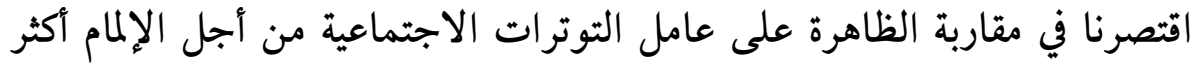

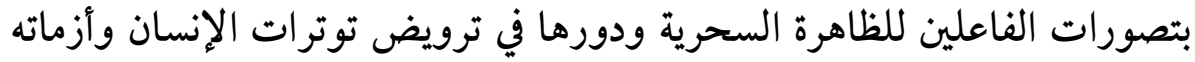

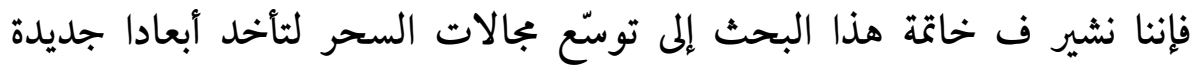

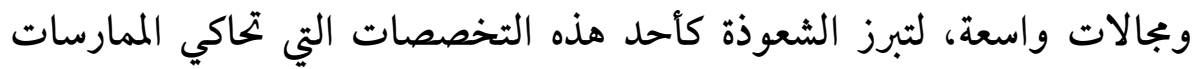

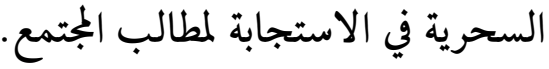

هذا وقد توصيّلت الدراسة إلى توضيح فكرة جدّ مهمّة وهي محاكات

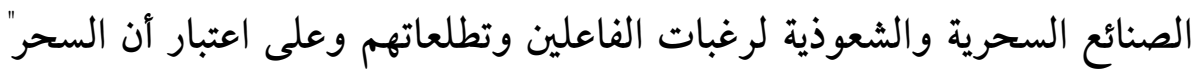

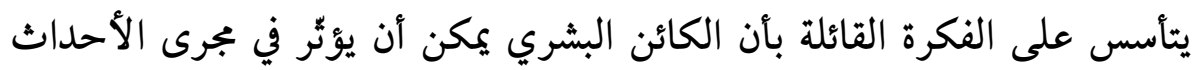
العادية بواسطة أدوات ما فوق طبيعية (38).

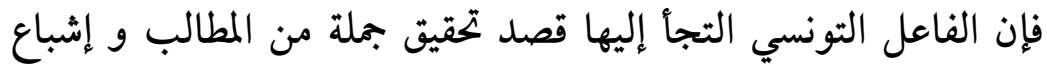

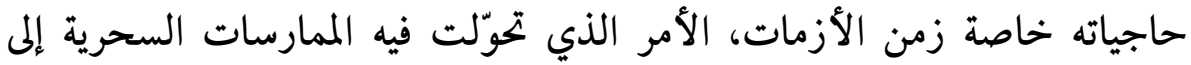

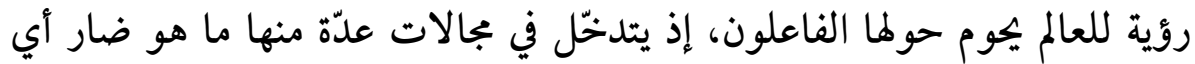

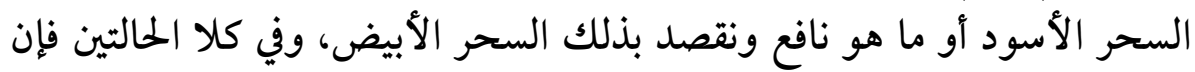

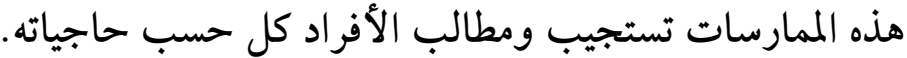

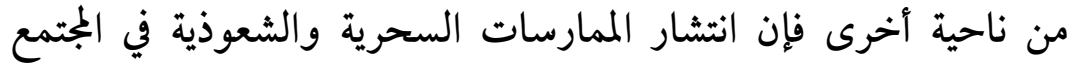

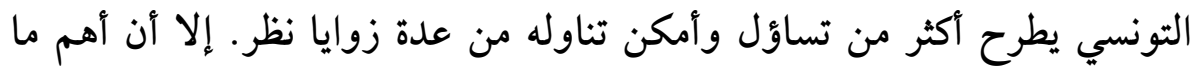

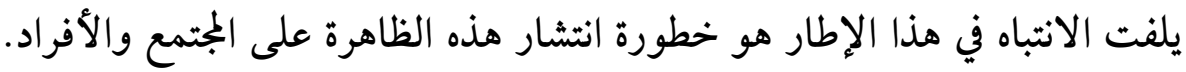
فكم هي عديدة الجرائم التي يتسبب فيها هؤلاء المشتغلون.

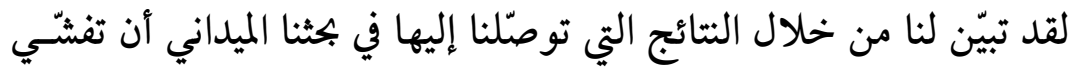

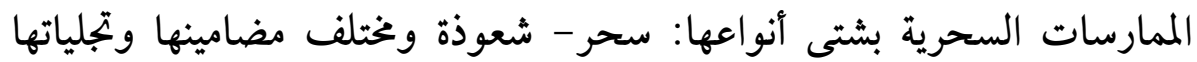




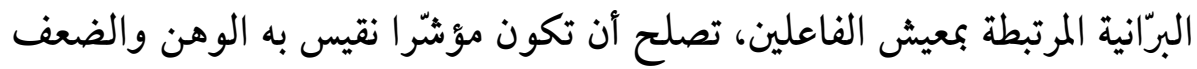

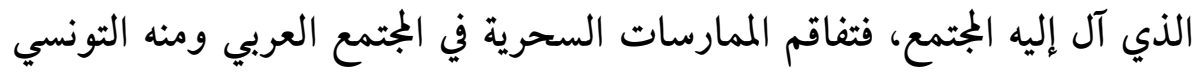

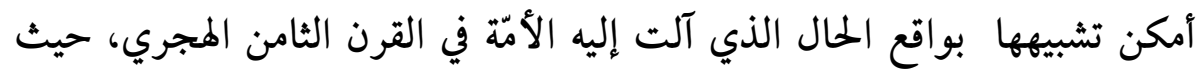

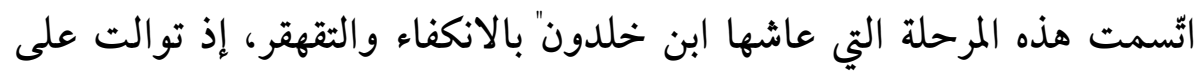

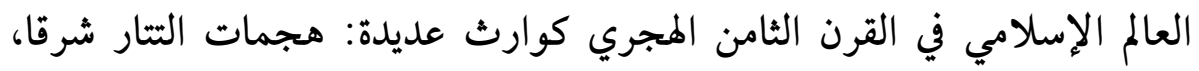

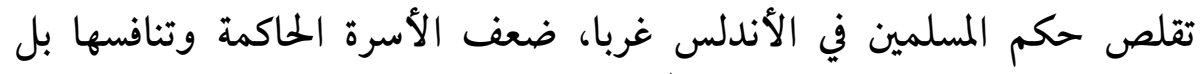

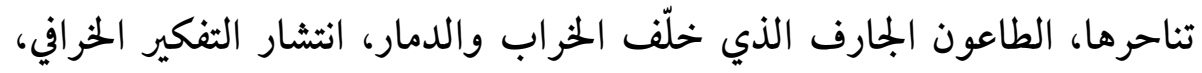

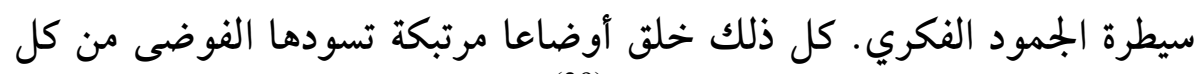

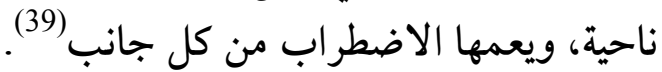




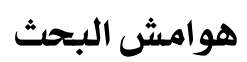

(1) Mauss (Marcel) \& Henri (Hubert), «Esquisse d'une théorie générale de la magie », (1902), in Mauss (Marcel), Sociologie et anthropologie, Paris, PUF, 1950, pp.13-17.

راجع في هذا الشأن: سيرجيميس فريزر، الغصن الذهبي: دراسة في السحر والدين، ترجمة

أحمد أبو زيد، الميئة المصرية العامة للتأليف والنشر، المطبعة الثقافية، مصر، 1971، ص 74.

(3) Doutte (Edmond), Magie et religion dans l'Afrique du Nord: La société musulmane du Maghrib, Alger, Typographie Adolphe Jourdan Imprimeur-Libraireéditeur 9, Place de la Régence, 1909, Livre numérisé en mode texte par: Alain Spenatto, p.603.

الأولى، (4) محمد زهير الحريري، السحر بين الحقيقة و الخيال، دار الإيمان، دمشق - بيروت، الطبعة 12085 -1220

(5) محمد أسليـم، هو امسش في السحـر، وكالة الصحافة العربية، القاهرة، 2001، ص 1.

${ }^{(6)}$ Boudon (Raymond), Les méthodes en sociologie, $10^{\mathrm{eme}}$ éditions, Paris, PUF, 1995, pp.86-96.

(7) Idem , pp.86-96.

(8)Boudon (Raymond), L'inégalité des chances, la mobilité sociale dans les sociétés industrielles, Ed. Armand colin, paris 1978, p. 58.

(9) لمزيد التعمق في هذا الجانب أنظر:

Mjouti (Mohamed), Hôpital psychiatrique et thérapies traditionnelles au Maroc, thèse pour le doctorat de 3ème cycle, Toulouse-le Mirail, 1983, p. 191

$$
\text { (10) راجع في هذا الشأن: }
$$

سعيد الحسين عبدولي، المدرمة والمستقبل في تصورات تلامذة بيئة ريفية: حالة منطقة سيدي علي بن عون من ولاية سيدي بوزيد مثالا تطبيقيا، شهادة الدراسات المعمقة في علم الاجتماع، كلية العلوم الانسانية والاجتماعية، تونس، 9 جوان 2006.

(11) مقابلة مع الساحر" الطبيب الرعواني" شوشان الممامي، القرية، أولاد شكر، في 28- 04.2010

(12) اسم الشهرة أو الكنية لمشعوذ مشهور في منطقة سيدي علي بن عون، والمعروف لدى جمهور

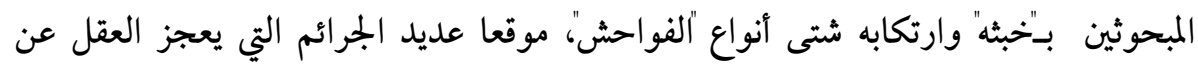


تصورها وذلك استنادا إلى التصريحات التي تلقيناها عبر المقابلات وما استنتجناه بالملاحظة المباشرة، وهو لا يزال يواصل عمله بنفس الوتيرة حتى بعد 14 جانفي 2011 تاريخ سقوط

(13) Durkheim (Émile), Les formes élémentaires de la vie religieuse, Paris, Le livre de poche, 1991, p125.

(14بداك شابحة، الوظيفة السوسويولجية للسحر عبر الأسطورة القبائلية- دراسة سوسويولجية،

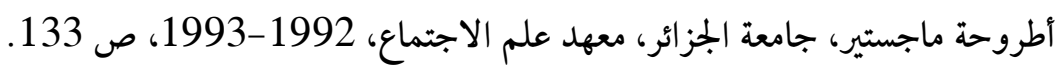

(15) Ziouziou (Abdallah), «Réflexions sur la thérapie traditionnelle» in Lamalif, $\mathrm{n}^{\circ}$ 143, Février-Mars, 1983, pp. 42-43.

${ }^{(16)}$ Doutte (Edmond), ibid, pp.311-317.

(17) حسن الشقرماني، المنقذ الثاني من السحر والسحرة، أفريقيا الشرق، الدار البيضاء، المغرب،

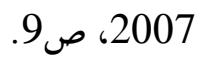

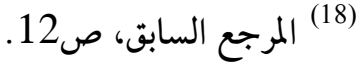

$$
\begin{aligned}
& \text { راجع في هذا الاطار: }
\end{aligned}
$$

Ziouziou (Abdallah) «Réflexions sur la thérapie traditionnelle» in Lamalif, $\mathrm{n}^{\circ}$ 143, Février-Mars, 1983, pp. 42-43.

(20) مقابلة مع الساحر" الطبيب الرعواني" شوشان الممامي، القرية، أولاد شكر، في 28- 04.2010

(21) اسم الطالب غير متداول في تونس، لكنه شائع الاستخدام في كل من الجزائر والمغرب، وقد

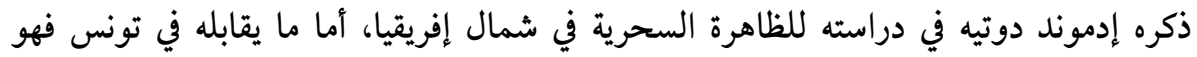

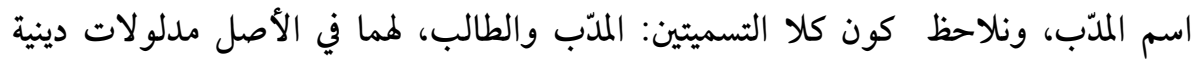
إسلامية أي الشيخ أو من له بركة بحكم تفقّه في الدين. لكن يطلقان أيضا على المشتغلين في السحر والشعوذة.

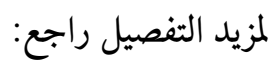

Doutte (Edmond), ibid, pp. 293-378.

عبد الرحيم تمام أبو كريشة، الطب الشعبي في الريف العربي، مكتبة النهضة المصرية،

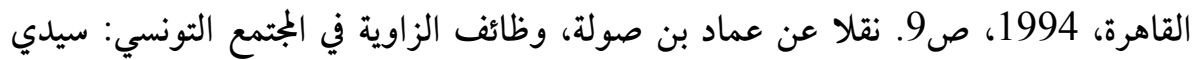


البشير نموذجا، شهادة الدكتوراه، كلية العلوم الإنسانية والاجتماعية بتونس، قسم علم

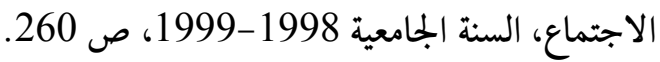

(23) عبد الرحيم تمام أبو كريشة، الطب الشعبي في الريف العربي، مكتبة النهضة المصرية، القاهرة، 1994، ص9. نقلا عن عماد بن صولة، وظائف الزاوية في المجتمع التونسي: سيدي التئي

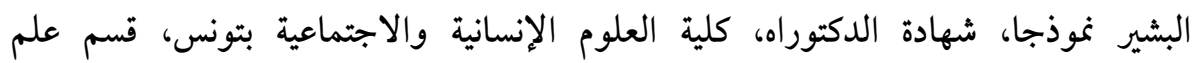

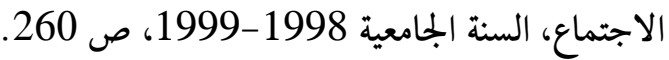

(24) Doutte (Edmond), ibid, p. 37.

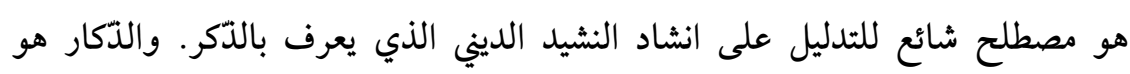

بالتالي المنشد ومن بين أبرز الأذكار التي ينشدها الذكارة هي : "يا عيّا جيناك زوّرا هائ ها عيا. (26) بداك شابحة، الوظيفة السوسويولجية للسحر عبر الأسطورة القبائلية-دراسة سوسويولجية المئية

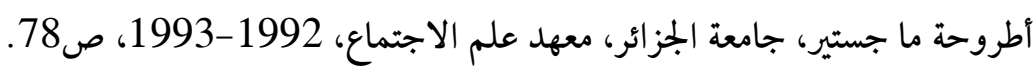

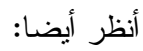

Doutte (Edmond), ibid, p 33-34.

(27) Foerster (H.V.), "On Self-Organizing Systems and their Environments", in Yovits (M.C.), Cameron (S.), Self-Organizing Systems, Oxford, London, New York, Pergamon Press, 1960, p.43-45

(28)بداك شبحة، الوظيفة السوسيولوجية للسحر عبر الأسطورة الأمازيغية - دراسة نفسية -

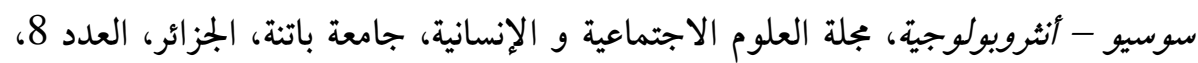

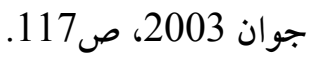

(29) Weber (Max), L'éthique protestante et l'esprit du capitalisme (1904-1905), Plon, 1964, Paris.

www.aslimnet.free.fr" حوار مع محمد أسليسم: "في ماهية السحـر ووجوده أو عدمه (30)

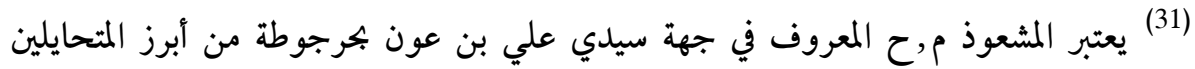

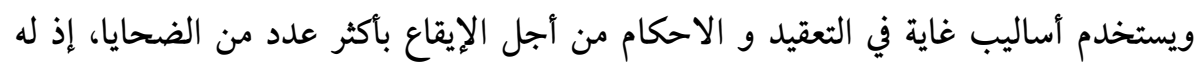
وسطاء في كافة الولايات التونسية يعملون على شهرته وينسقون معه في رسم الحيل الحيل والخطط.

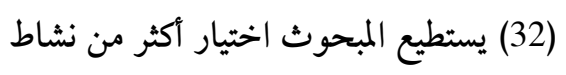

(33) Jamous (Raymond), Honneur et Baraka: Les structures sociales traditionnelles dans le Rif, éd Cambridge university press et Maison Des sciences de l'homme, Paris 1981, p.204. 
(34) ويليام سيبروك، السحر قوته في العالم اليوم، ترجمة سليم عبد الأمير حمدان، المدى للثقافة والنشر، سورية، 2009، صيام سيروك.

(35) Lévi-Strauss (Claude), Anthropologie structurale, Paris, Plon, 1958, p.184.

(36) أحمد البوني، اللؤلؤ والمرجان في تسخير ملوك الجان، المكتبة الثقافية، لبنان، 1999، ص2. (37) المصدر السابق، ص 25. (38) Azria (R.) \& Hervieu-Léger (D.), « MAGIE / SORCELLERIE », in Dictionnaire des faits religieux, Paris, PUF, 2010, p.679-685.

(39) محمد عابد الجابري، العصبية والدولة، دار الشؤون الثقافية، بغداد، من دون تاريخ، ص 